\title{
Matching policy and science: Rationale for the ' 4 per 1000 - soils for food security and climate' initiative
}

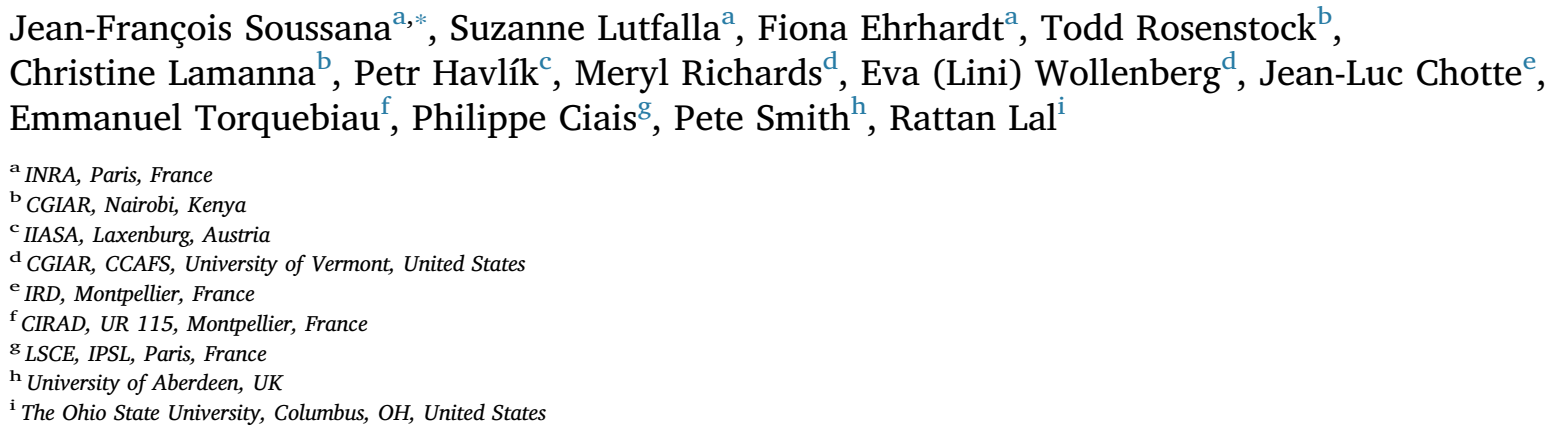

\section{A R T I C L E I N F O}

\section{Keywords:}

Soil organic carbon

Carbon sequestration

Climate change

\begin{abstract}
A B S T R A C T
At the 21st session of the United Nations Framework Convention on Climate Change (UNFCCC, COP21), a voluntary action plan, the ' 4 per 1000 Initiative: Soils for Food Security and Climate' was proposed under the Agenda for Action. The Initiative underlines the role of soil organic matter (SOM) in addressing the three-fold challenge of food and nutritional security, adaptation to climate change and mitigation of human-induced greenhouse gases (GHGs) emissions. It sets an ambitious aspirational target of a 4 per 1000 (i.e. $0.4 \%$ ) rate of annual increase in global soil organic carbon (SOC) stocks, with a focus on agricultural lands where farmers would ensure the carbon stewardship of soils, like they manage day-to-day multipurpose production systems in a changing environment. In this paper, the opportunities and challenges for the 4 per 1000 initiative are discussed. We show that the 4 per 1000 target, calculated relative to global top soil SOC stocks, is consistent with literature estimates of the technical potential for SOC sequestration, though the achievable potential is likely to be substantially lower given socio-economic constraints. We calculate that land-based negative emissions from additional SOC sequestration could significantly contribute to reducing the anthropogenic $\mathrm{CO}_{2}$ equivalent emission gap identified from Nationally Determined Contributions pledged by countries to stabilize global warming levels below $2{ }^{\circ} \mathrm{C}$ or even $1.5^{\circ} \mathrm{C}$ under the Paris agreement on climate. The 4 per 1000 target could be implemented by taking into account differentiated SOC stock baselines, reversing the current trend of huge soil $\mathrm{CO}_{2}$ losses, e.g. from agriculture encroaching peatland soils. We further discuss the potential benefits of SOC stewardship for both degraded and healthy soils along contrasting spatial scales (field, farm, landscape and country) and temporal (year to century) horizons. Last, we present some of the implications relative to non- $\mathrm{CO}_{2} \mathrm{GHGs}$ emissions, water and nutrients use as well as co-benefits for crop yields and climate change adaptation. We underline the considerable challenges associated with the non-permanence of SOC stocks and show how the rates of adoption and the duration of improved soil management practices could alter the global impacts of practices under the 4 per 1000 initiative. We conclude that the 4 per 1000 initiative has potential to support multiple sustainable development goals (SDGs) of the 2030 Agenda. It can be regarded as no-regret since increasing SOC in agricultural soils will contribute to food security benefits that will enhance resilience to climate change. However, social, economic and environmental safeguards will be needed to ensure an equitable and sustainable implementation of the 4 per 1000 target.
\end{abstract}

\footnotetext{
* Corresponding author at: INRA, Paris, France.

E-mail address: jean-francois.soussana@inra.fr (J.-F. Soussana).
} 


\section{Introduction}

Anthropogenic emissions of greenhouse gases (GHGs) have strongly influenced the global carbon (C) cycle, leading to an increase of the atmospheric concentration of carbon dioxide, $\mathrm{CO}_{2}$, to ca. 400 parts per million by volume (ppm) (Dlugokencky and Tans, 2017). In addition to $\mathrm{CO}_{2}$, atmospheric concentrations of nitrous oxide, $\mathrm{N}_{2} \mathrm{O}$, and methane, $\mathrm{CH}_{4}$, are also increasing. Together, increasing atmospheric concentrations of GHGs are influencing the radiative forcing and increasing the Earth's mean temperature. Therefore, reducing atmospheric concentration of $\mathrm{CO}_{2}$ and other GHGs is important to mitigate climate change and avoid increased volatility (extreme events) and adverse manifestations of regional and global climate change (IPCC, 2013). Today, the land surface including non-managed and managed ecosystems, the latter having by far the largest area, are assessed to be a net source of $\mathrm{CO}_{2}$ equivalent $\left(\mathrm{CO}_{2} \mathrm{eq}\right)$ to the atmosphere (Tian et al., 2016), mainly because the warming effect of $\mathrm{CH}_{4}$ and $\mathrm{N}_{2} \mathrm{O}$ emissions from agriculture overcomes the cooling effect of the global carbon sink.

Agriculture (mainly $\mathrm{CH}_{4}$ and $\mathrm{N}_{2} \mathrm{O}$ emissions from established cropland and pasture, and $\mathrm{CO}_{2}$ emissions from peat drained from agriculture) and land-use change (mainly forest clearing for agricultural expansion in tropical regions) are major sources of land-based GHGs, responsible for approximately $24 \%$ of total GHG emissions (Smith et al., 2014 in IPCC, 2014). Carbon losses from soils have a large role in landbased emissions. In particular, peatland drainage accounts for one-third of global cropland GHG emissions (Carlson et al., 2017). For instance, the tropical peatland C stocks in South East Asia upon which agriculture is established are vulnerable to fires induced by drought, resulting into large emissions during dry El Niño years, and released 2 gigatons of carbon (GtC, $1 \mathrm{GtC}$ corresponds to 1 petagram of carbon) in 1997 and 0.5 GtC in 2015 (GFED, 2016; Page et al., 2002; Yin et al., 2016).

Annual crop losses of $0.3 \%$ per year have been estimated and the continuation of this trend could lead to a global yield decline of $10 \%$ by 2050 (FAO and ITPS, 2015). Land degradation poses a threat to agriculture, and climate change may accelerate the rate of degradation with major impacts on food security and wellbeing of small farmers.

In this context, the role of land carbon management needs to be reexamined. Namely, soil organic carbon (SOC) sequestration, afforestation and reforestation including tree planting through agroforestry, are the only land-based negative emissions (i.e. removing $\mathrm{CO}_{2}$ from the atmosphere) which are readily available at low cost (Smith et al., 2016). Yet, SOC sequestration is currently not considered in global climate stabilization scenarios (IPCC, 2014). Concerns about the permanence of sequestered SOC, long-term changes in agricultural systems and the difficulty of detecting improvements have hitherto limited the attention given to SOC sequestration. Carbon stocks in the upper soil layers respond within years to changes in land use and management, providing an opportunity to store carbon and remove $\mathrm{CO}_{2}$ from the atmosphere in the short term, which is relevant in the context of the Nationally Determined Contributions (NDC) targets set to 2030. Soils also carry a significant potential for carbon sequestration, especially through restoration measures on degraded soils (Lal, 2010).

The Paris agreement at the 21st Conference of Parties (COP21) of the United Nations Framework Convention on Climate Change (UNFCCC), calls for limiting global warming well below $2^{\circ} \mathrm{C}$, and to pursue efforts to limit the temperature increase even further to $1.5^{\circ} \mathrm{C}$. It also requests increasing the ability to adapt to the adverse impacts of climate change and foster climate resilience and low GHG emissions development, through pathways that will not threaten food production. Nevertheless, under current policy, aggregate anthropogenic GHG emissions could reach $55 \mathrm{GtCO}_{2}$ equivalents in 2030 resulting in a $60 \%$ likelihood (Fawcett et al., 2015) of reaching global warming levels by 2100 relative to preindustrial levels of $3{ }^{\circ} \mathrm{C}$.

In order to meet the Paris Agreement objectives, anthropogenic emissions will most likely need to peak within the next 10 years and continue to decrease during the following decades up to a value close to zero, or even to a net GHG removal by the end of the century. Alternative scenarios such as 'overshoot scenarios' with continued emissions followed by very rapid and intense emission reductions bear a risk of warming above $2{ }^{\circ} \mathrm{C}$ (Walsh et al., 2017). Within the agriculture sector, reducing $\mathrm{N}_{2} \mathrm{O}$ and $\mathrm{CH}_{4}$ mitigation alone along with plausible development pathways cannot deliver the level of agricultural mitigation (ca. $1 \mathrm{GtCO}_{2}$ eq per year by 2030) required to stay within the $2{ }^{\circ} \mathrm{C}$ global warming objective (Wollenberg et al., 2016). In fact, about $90 \%$ of the total technical mitigation potential in agriculture (excluding bioenergy and improved energy use) is based on SOC sequestration options (Smith et al., 2008; Paustian et al., 2016).

At COP21, 103 countries have set mitigation and adaptation targets in agriculture, and 129 included targets related to other land use including forests and degraded land (Richards et al., 2016). Yet, the proposed actions are diverse across countries and are not detailed, which highlights the need for a shared and ambitious target for landbased mitigation and adaptation that could provide a bridge to remain below the $2{ }^{\circ} \mathrm{C}$ global warming level. Such a voluntary action plan, the ' 4 per 1000 Initiative: Soils for Food Security and Climate' was launched at COP21 and is supported by 39 countries and more than 190 organizations as of June 2017 (4 per 1000, 2017). This initiative sets a global aspirational goal to increase SOC stock at an annual rate of $0.4 \%$ per year (or 4 per 1000) in all land uses, including forests. If such increases were possible to implement fully by 2030 , this SOC sequestration target would double the total mitigation encompassed by the COP21 Nationally Determined Contributions (NDCs), compared to a middle of the road baseline scenario of the fifth assessment report of the Intergovernmental panel on climate change (IPCC, AR5) (UNEP, 2015). Here, we assess the implications and challenges created by the 4 per 1000 aspirational target for global soil carbon and we discuss the following questions: is 4 per 1000 technically feasible? How might it be achieved? What are the benefits for yields and for climate change mitigation and adaptation? What are the main barriers?

\section{Materials and methods}

\subsection{Global SOC stocks by depth and by biome}

Global SOC stock was interpolated between estimates over $30 \mathrm{~cm}$ (Batjes, 1996; Hiederer and Köchy, 2011), 100 and $200 \mathrm{~cm}$ (Batjes, 1996; Scharlemann et al., 2014) using a third order polynomial fit (see Supplementary material, S.M., Fig. S1). The distribution of SOC stock by biome at $1 \mathrm{~m}$ depth was derived from Table 3 of Jobbágy and Jackson (2000) and the fraction of this SOC stock to $40 \mathrm{~cm}$ was calculated by biome (crops, grasslands, forests) from their Fig. 5 (see Supplementary material).

\subsection{Yields and SOC sequestration}

The estimation of the potential impact of an agricultural SOC increase by $0.4 \%$ per year on crop yields is derived from 32 studies. The 32 studies were identified from a reference library compiled for a metaanalysis that reviewed the impact of agriculture practices on productivity, adaptive capacity and mitigation, including yield and SOC outcomes, in developing countries (Rosenstock et al., 2016). The 32 selected articles met the following three criteria: (i) conducted over four years or longer (13.6 \pm 8.5 years, mean \pm sd), (ii) reported data on both yield and SOC, and (iii) contained paired data on the impacts of both a conventional and an improved agricultural management practice such as organic fertilizer use, crop and soil management, water management and intercropping agroforestry (see references included in Supplementary material). Less than $10 \%$ of the data were derived from studies with conservation agriculture (CA) and reduced tillage. A Standard Major Axis regression (Legendre and Legendre, 2012) was used to correlate the relative changes in yields and in SOC, since none of these two variables can be considered as independent. 


\section{Results and discussion}

\subsection{Soil depth and the global 4 per 1000 target}

Not accounting for $\mathrm{C}$ in permafrost, the world's soils contain a total SOC stock of about $1500 \pm 230 \mathrm{GtC}$ down to $1 \mathrm{~m}$ depth, which is equivalent to twice the amount of $\mathrm{C}$ as $\mathrm{CO}_{2}$ in the atmosphere (i.e., 828 GtC in 2011, Le Quéré et al., 2015). The early recognition that the stock of SOC over 0-3 $\mathrm{m}$ is at least twice as much as that represented by $\mathrm{CO}_{2}$ $\mathrm{C}$ in the atmosphere (Bolin et al., 1986) has led to the proposal that an annual increase in this reservoir by $0.4 \%$ per year (a rate of 4 per 1000) would store as much $\mathrm{C}$ as the anthropogenic emission of fossil $\mathrm{C}$ (Balesdent and Arrouays, 1999). However, no claim was made by these authors that it would be technically feasible to increase SOC stock over the full soil depth $(0-3 \mathrm{~m})$ at an annual growth rate of $0.4 \%$.

Indeed, there are large stores of soil organic matter (SOM) at depth, but they were formed over millennia, as deep soil carbon has a slow accumulation rate (Fontaine et al., 2007). In contrast, top soil SOM can increase or decrease rapidly after changes in land use and agricultural practices (Conant et al., 2017) because it is directly connected to input from below-ground productivity, and because most of the decomposition occurs in the top soil. Thus, agricultural top soil SOC is frequently observed to increase at rates often equal or higher than the aspirational target of $+0.4 \%$ per year (Minasny et al., 2017).

As shown in Table 1, if it were possible to increase the global top SOC stock by $0.4 \%$ per year, this would provide a global SOC sequestration of 2.8 and $3.4 \mathrm{GtC} \cdot \mathrm{yr}^{-1}$ over $0-30$ and $0-40 \mathrm{~cm}$, respectively. These values are in the range $\left(2.6-5.0 \mathrm{GtC} \cdot \mathrm{yr}^{-1}\right)$ of technical SOC sequestration rates achievable when harnessing all land use types and combining different sequestration practices to maximize soil $\mathrm{C}$ gains (Lal, 2010; Smith et al., 2013). In contrast, aiming to increase all SOC (down to $1 \mathrm{~m}$ or to $3 \mathrm{~m}$ ) at a rate of $0.4 \%$ per year is not plausible, as it would require SOC sequestration rates that are higher than even the most optimistic estimates (Table 1).

\subsection{Agricultural, land management and forestry practices}

The ecosystem C balance (ECB) can be calculated from the sum of gross inputs and outputs of inorganic and organic $\mathrm{C}$ to the ecosystem: (i) carbon trace gases exchanged with the atmosphere (i.e. $\mathrm{CO}_{2}$; $\mathrm{CH}_{4}$; volatile organic compounds, VOC; and emissions during fires), (ii) organic $\mathrm{C}$ imports (compost, manures) and exports (harvests, animal products), (iii) dissolved $\mathrm{C}$ lost in waters (dissolved organic and inorganic $\mathrm{C}$ ) and lateral transport of soil $\mathrm{C}$ through erosion. ECB $\left(\mathrm{tC} \cdot \mathrm{ha}^{-1} \cdot \mathrm{y}^{-1}\right)$, which is the measurable change of ecosystem $\mathrm{C}$ stock, can be calculated from the mass balance of these fluxes (Soussana et al., 2010):

$E C B=N P P-R_{h}+F_{\text {manure }}-F_{C H 4-C}-F_{V O C}-F_{\text {fire }}-F_{\text {harvest }}-F_{\text {animal-pro- }}$ ducts $-F_{\text {leach }}-F_{\text {erosion }}$

Where NPP and $R_{h}$ are the net primary productivity (NPP) and the heterotrophic (soil + animal) respiration, $F_{C H 4-C}, F_{V O C}$ and $F_{f i r e}$ are trace-gas $\mathrm{C}$ losses from the ecosystem, through soil and enteric methane emissions, volatile organic compounds and fires, respectively. $F_{\text {manure }}$ is the organic $\mathrm{C}$ input through manure and other amendments application, while $F_{\text {harvest }}$ and $F_{\text {animal-products }}$ are organic $C$ exports in crop and grassland harvests and in milk and meat products, respectively. $F_{\text {leach }}$ and $F_{\text {erosion }}$ are organic (and/or inorganic) $C$ losses through leaching and erosion, respectively. Eq. (1) has dominant terms at annual time scale, which usually are $N P P, R_{h}, F_{\text {manure }}$ and $F_{\text {harvest }}$, with other fluxes being relatively small on short time scales but becoming important when considering ECB on multi-decadal time scales. Erosion is a carbon loss at site scale, for instance wind erosion organic carbon losses range from 0.3 to $1.0 \mathrm{GtC} \cdot \mathrm{y}^{-1}$ (Chappell et al., 2016). Although the net C balance of erosion removal, compensatory soil sink, transport and re-deposition processes is highly uncertain, it is believed to be a net C sink at global scale (Wang et al., 2017). Nevertheless, even if erosion could potentially induce a sink for atmospheric $\mathrm{CO}_{2}$, strong agricultural policies are needed to prevent or reduce soil erosion, in order to maintain primary productivity and soil health (Lugato et al., 2016).

Most of the fluxes composing Eq. (1) have contrasted values depending on soil, climate, land-use and land management. For instance, $\mathrm{CH}_{4}-\mathrm{C}$ emissions from paddy rice and wet grasslands are high, but $\mathrm{CH}_{4}{ }^{-}$ $C$ oxidation is documented in many arable crop and forest systems (Conrad, 2009).

$E C B=\triangle S O C+\triangle A G C$

The ecosystem $\mathrm{C}$ balance is the sum of a below-ground component ( $\triangle S O C$, net change in SOC stock) and of an above-ground component ( $\triangle A G C$, net change in the $\mathrm{C}$ stock accumulated in above-ground biomass). Hence, the soil $\mathrm{C}$ balance $(\triangle S O C)$ can be derived from ECB by accounting for changes in above-ground $\mathrm{C}$ stock $(\triangle A G C)$, which are typically small with annual crops and grasslands, intermediate with perennial crops, rangelands and agroforestry, and large with forestry:

$\Delta S O C=\left(N P P-R_{h}-\Delta A G C\right)+\left(F_{\text {manure }}-\quad F_{\text {harvest }}-F_{\text {animal-products }}-F_{C H 4}\right.$ C) $-\left(F_{\text {erosion }}+F_{\text {fire }}+F_{\text {leach }}+F_{\text {VOC }}\right)$

Eq. (3) shows the three categories of fluxes that govern $\triangle S O C$ at the ecosystem scale: the flux of organic carbon partitioned below-ground (NPP- $R_{h}-\triangle A G C$ ), the human appropriation of above-ground carbon ( $\left.F_{\text {manure }}-F_{\text {harvest }}-F_{\text {animal-products }}-F_{C H 4-C}\right)$ and the carbon losses at ecosystem scale $\left(F_{\text {erosion }}+F_{\text {fire }}+F_{\text {leach }}+F_{\text {VOC }}\right)$.

Management strategies to increase $\triangle \mathrm{SOC}$ target these three categories in different ways:

- Soil conservation. Soil conservation requires reducing $\mathrm{C}$ losses from the ecosystem e.g. by avoiding fires, reducing erosion and leaching (i.e. reducing $F_{\text {erosion }}, F_{\text {fire }}$ and $F_{\text {leach }}$ ). Many conservation practices can be combined and these have been reviewed by the UN Food and Agriculture Organization (FAO) and the Intergovernmental

Table 1

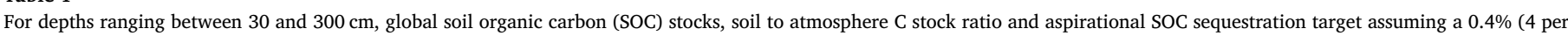

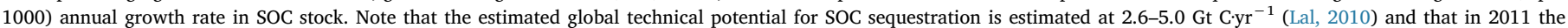
atmospheric $\mathrm{C}$ content as $\mathrm{CO}_{2}$ reached 828 GtC (Le Quéré et al., 2015).

\begin{tabular}{|c|c|c|c|c|c|}
\hline Soil depth & SOC stock & Source & $\begin{array}{l}\text { Soil: atmosphere C stock ratio } \\
\text { in } 2011\end{array}$ & $\begin{array}{l}4 \text { per } 1000 \text { target SOC } \\
\text { sequestration }\end{array}$ & Source \\
\hline $\mathrm{cm}$ & $\mathrm{GtC}$ & & $\mathrm{GtC} \cdot \mathrm{yr}^{-1}$ & & \\
\hline $0-30$ & $690 \pm 90$ & $\begin{array}{l}\text { Batjes (1996); Hiederer and Köchy } \\
\text { (2011) }\end{array}$ & 0.8 & $2.8 \pm 0.36$ & - \\
\hline $0-40$ & 860 & Interpolation, see Fig. S1 (S.M.) & 1.0 & 3.4 & - \\
\hline $0-100$ & $1500 \pm 230$ & $\begin{array}{l}\text { Batjes (1996); Scharlemann et al. } \\
\text { (2014) }\end{array}$ & 1.8 & $6.0 \pm 0.92$ & Chabbi et al. (2017) \\
\hline $0-300$ & 2344 & Jobbágy and Jackson (2000) & 2.8 & 9.4 & $\begin{array}{l}\text { Balesdent and Arrouays (1999); cited by } \\
\text { Minasny et al. (2017) }\end{array}$ \\
\hline
\end{tabular}


Technical Panel on Soils (ITPS) in a dedicated report (FAO and ITPS, 2015) and are studied by the WOCAT network (WOCAT, 2017). Soil conservation also has implications for other fluxes which are directly (e.g. $F_{\text {harvest }}$ ), or indirectly (e.g. $R_{h}$ ) controlled by agricultural management. For instance, no-till, cover crops, direct drilling into mulch can be used to protect cultivated soils from erosion and will have feedbacks on plant production and harvest, through soil moisture and nutrients.

- Carbon management. C management aims at increasing ECB by accumulating above-ground biomass (e.g. in forests, in agro-forestry) and by sequestering SOC (in all ecosystems). Protecting SOC stocks requires avoiding adverse land use change and management practices (e.g. deforestation, ploughing of grasslands, soil sealing, etc.), avoiding drainage and cultivation of organic soils (e.g. drained peatlands). $\mathrm{C}$ management also has strong implications for the balance between primary productivity (NPP), soil and animal respiration $\left(R_{h}\right)$, manures and harvests $\left(\mathrm{F}_{\text {manure }}, \mathrm{F}_{\text {harvest }}\right)$. Avoiding overgrazing (which reduces NPP and increases $F_{C H 4-C}$ and $R_{h}$ ), balancing SOM decomposition with the supply of manures, crop residues and litter, and increasing the mean annual NPP allow to increase $\triangle \mathrm{SOC}$ in agricultural systems (Jansson et al., 2010).

- Meta-analyzes conducted in recent years and covering the entire soil column (Luo et al., 2010; Virto et al., 2012) suggested no significant positive difference in $\triangle S O C$ on average in no-till soils, although some increase in organic matter (and hence $\mathrm{C}$ ) concentration in the $15-20 \mathrm{~cm}$ layer of top-soil is usually observed. Positive effects such as reduced soil erosion and improved water retention and infiltration, may increase crop yields and soil C in dry conditions under notill, because of reduced soil evaporation (caused by mulch), but apparently not in cool-moist climates given increased risks of waterlogging (Pittelkow et al., 2015; Powlson et al., 2014). In addition, in humid regions no-till may reduce crop yields and soil $\mathrm{C}$ due to increased weed development (Giller et al., 2009; Pittelkow et al., 2015). SOM stabilization would be increased through rhizodeposition and root litter inputs (Dignac et al., 2017) and could therefore be higher with perennial plant species compared to annuals. Indeed, Jobbágy and Jackson (2000) have shown that the vertical distribution of SOC in contrasted soil profiles corresponds to that of the vertical root distribution. Systems mixing perennials and annual crops (e.g. agroforestry) and crop-grass rotations can therefore be beneficial for SOC sequestration (Soussana and Lemaire, 2014). Tropical agroforestry trees can show impressive root growth rates. Roots of Sesbania sesban in an agroforestry fallow in Zambia were found growing to a depth of $7 \mathrm{~m}$ after 2 years, at a rate of about $1 \mathrm{~cm} \cdot \mathrm{day}^{-1}$. This represents a carbon input between 0.6 and $1 \mathrm{tC} \cdot \mathrm{ha}^{-1}$ (Torquebiau and Kwesiga, 1996).

- Agricultural and forestry intensification. Shifting from natural to planted forests, from semi-natural to sown grasslands and intensifying arable crop production by use of modern varieties and of supplies of fertilizers and pesticides inputs has been largely used to increase food, feed and fiber production often resulting in NPP increases, but not necessarily improving ECB and $\triangle \mathrm{SOC}$, since the human appropriation of NPP through harvests, grazing and fires has been increasing (Haberl et al., 2014).

Adoption of improved agronomic practices results in relative annual SOC increases that are often in excess of $0.4 \%$ in tropical grasslands (Assad et al., 2013) and in temperate and tropical cropping systems (Stockmann et al., 2013). A synthesis of internationally distributed long-term field crop trials (Minasny et al., 2017) has recently confirmed this finding and has shown that the relative growth rate of SOC stocks is usually higher when starting from degraded soils (1.5\% per year, on average, for an initial SOC stock of $20 \mathrm{tC} \cdot \mathrm{ha}^{-1}$ ) than from C rich soils ( $0.4 \%$ per year for an initial SOC stock of $\left.80 \mathrm{tC} \cdot \mathrm{ha}^{-1}\right)$.

Agricultural practices which can be used to store additional SOC include crop species and varieties with greater root mass and with deeper roots, use of $\mathrm{N}$-fixing legumes in $\mathrm{N}$-deprived soils, use of cover crops during fallow periods, use of crop rotations providing greater $\mathrm{C}$ inputs, increased residue retention and addition of amendments such as compost and biochar (Paustian et al., 2016).

These practices may reduce organic $\mathrm{C}$ losses (e.g. by reducing fires, overgrazing, harvests of timber and soil erosion), or increase organic $\mathrm{C}$ returns to the soil (crop residues, manures) and, moreover, change the balance between photosynthesis and ecosystem respiration. The latter can be achieved by increasing crop photosynthesis (e.g. through cover crops, intercropping, agroforestry) and by minimizing soil disturbance (e.g. conservation agriculture, CA). Large gains in crop carbon balance can also be obtained through improved crop cultivars, use of $\mathrm{N}$-fixing legumes and of organic and inorganic fertilizers, thereby enhancing the amounts of crop residues returning to the soil. Improved water management is also a strong driver of primary productivity and can complement the aforementioned practices. The use of cover crops increased SOC stock on average by $0.32 \mathrm{tC} . \mathrm{ha}^{-1} \cdot \mathrm{y}^{-1}$ over 50 years (Poeplau and Don, 2015). With grasslands, seeding highly productive $C_{4}$ grasses (e.g. Brachiaria sp.) and applying $\mathrm{N}$ and $\mathrm{P}$ fertilizers under tropical conditions in Brazil provides high rates of soil $\mathrm{C}$ sequestration, especially when restoring degraded pastures (Assad et al., 2013; Braz et al., 2013). A literature review of SOC storage in Sub-Saharan Africa showed that 79 and $63 \%$ of the observations in the published studies had relative rates that were larger than $0.4 \%$ per year in agroforestry and CA respectively (Corbeels et al. (in prep.)).

\subsection{Co-benefits for food security and climate change adaptation}

Practices that sequester SOC also tend to improve food security and climate change adaptation. With increasing SOC, co-benefits for yields (ca. 0.07 ton (t) of dry matter/t SOC sequestration) could be obtained each year under tropical conditions (Lal, 2006). Improving SOC stock by one ton $\mathrm{C}$ per hectare would have the potential to increase grain production in developing countries by 24-40 million $\mathrm{t} \cdot \mathrm{y}^{-1}$ (Lal, 2006). Hijbeek et al. (2017) when looking for a similar effect across a wide range of crops in Europe, found that the mean additional yield effect of organic inputs was not significant but a significant effect for root and tuber crops, spring sown cereals, and for crops for very sandy soils or wet climates. They also reported a significant correlation between increase in attainable yields and increase in SOM content.

In the literature review presented here, we compiled 32 published studies from developing countries reporting both changes in grain yields and in top-soil SOC stocks, 4 years or more after changes in management practices (see Materials and Methods section and Supplementary material). The corresponding field experiment data with corn, rice, wheat and beans show considerable scatter in the effects of improved agricultural practices, with some studies reporting large annual increases in crop productivity (up to $+40 \%$ ) and in topsoil SOC stocks (up to $+8 \%$ ) (Fig. 1). Despite this scatter, grain crop yield increases are significantly $(\mathrm{P}<0.012)$ and positively correlated with the relative change in SOC stock. On average, across these studies in Africa, Asia and Latin America, a 1.3\% annual increase in crop grain yields was associated with a $0.4 \%$ annual increase in SOC stock (Fig. 1). This positive correlation confirms that there are win-win strategies combining SOC sequestration and increasing crop yields in developing countries.

When including a positive effect of soil C mitigation on crop yields (based on Lal, 2006, who assumed a lower yield enhancement than the regression shown in Fig. 1), it was found in the global modeling study of Frank et al. (2017) that the average calorie deficit in developing countries, under $2{ }^{\circ} \mathrm{C}$ and $1.5^{\circ} \mathrm{C}$ global warming constraints, could be reduced below $100 \mathrm{kCal}$ per capita and per day (ca. $4 \%$ of daily dietary energy availability). Hence, SOC sequestration would have large cobenefits for food security compared to land-based mitigation policies not including SOC sequestration, since these land-based mitigation 


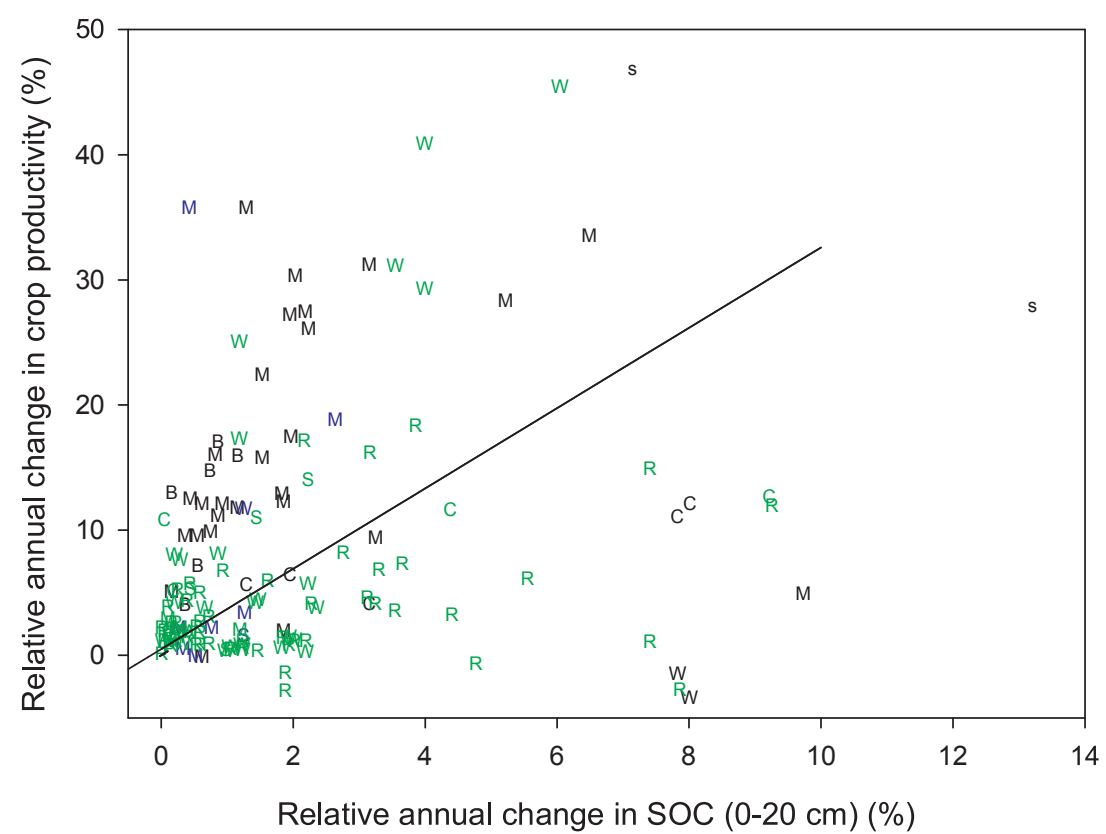

Fig. 1. Relative annual changes in crop productivity and in soil organic carbon stock (over $0-20 \mathrm{~cm}$ ) (\%) after changes in land management improving soil carbon. The results correspond to a meta-analysis of 32 papers, reporting 151 relevant comparisons of location, practice, and crops over 4 years or more. Crop species: B, beans; C, cassava; M, maize; $\mathrm{P}$, sweet potatoes; $\mathrm{R}$, rice; $\mathrm{S}$, soybean; s, sorghum; $\mathrm{W}$, wheat. Field experiment regions: Africa (Black); Asia (Green); Latin America (Blue). The solid line is the Standard Major Axis regression for all data points $(n=151$, Spearman's rank correlation: $y=0.495+3.21 \mathrm{x}$; $r=0.205, \quad P<0.012$ ). See references and information in Supplementary material. (For interpretation of the references to colour in this figure legend, the reader is referred to the web version of this article.) policies involve a rise in food prices (due e.g. to pressure on arable land) with calorie availability losses exceeding $300 \mathrm{kCal}$ per capita per day in developing countries under the $1.5^{\circ} \mathrm{C}$ target (Frank et al., 2017).

In addition, SOC sequestration helps reduce climate induced yield variability (Pan et al., 2009) by improving water availability to plants through SOM mediated improvements in soil structure, water infiltration and water holding capacity, thereby reducing risks of soil-related droughts as well as flooding since infiltration reduces peak flows (Herrick et al., 2013). Increased SOC content also leads to improved soil biological properties (Guimarães et al., 2013). Moreover, restoring degraded forests and expanding tree cover in agricultural landscapes could reduce the local magnitude of heat waves and induce benefits for the hydrological cycle and for the micro-climate (Ellison et al., 2017). Thus, restoring degraded soils and expanding agroforestry have large potential for climate change adaptation of agriculture, for yield increases and for the development of resilient production systems, especially under tropical conditions (Branca et al., 2013; Lipper et al., 2014). Therefore, the adoption of land management practices supporting SOC sequestration could be enhanced in developing countries by the need for rapid climate change adaptation, rather than by greenhouse gas mitigation concerns.

\subsection{To which extent could the 4 per 1000 target contribute to atmospheric carbon stabilization?}

In the current state of the global carbon cycle (Fig. 2A), approximately half of the anthropogenic emissions of $\mathrm{CO}_{2}-\mathrm{C}$ are compensated by the land and ocean carbon sinks. Therefore, if it was at all possible to enhance within a few years the land carbon sink by fully harnessing the total technical potential of SOC sequestration across all land use types $\left(3.4 \mathrm{GtC} \cdot \mathrm{y}^{-1}\right)$ (see Section 3.1) and by halting net deforestation (0.9 $\left.\mathrm{GtC} \cdot \mathrm{y}^{-1}\right)$, the atmospheric growth of $\mathrm{CO}_{2}\left(4.3 \mathrm{GtC} \cdot \mathrm{y}^{-1}\right)$ would be stopped. This is only a thought experiment however, since:

- It may take decades to fully implement the SOC sequestration technical potential and this would also require high $\mathrm{CO}_{2}$ prices, since the economic potential of SOC sequestration in agriculture is substantially lower than the technical potential even for carbon prices up to 100 USD per ton $\mathrm{CO}_{2}$ (see Section 3.5)

- In 2030, with full implementation of the conditional NDCs from the Paris agreement, anthropogenic emissions from fossil fuels and cements should reach $10.9 \mathrm{GtC}(+22 \%$ compared to current, Fawcett et al., 2015), with an additional $0.76 \mathrm{GtC}$ emitted by net land use change ( $-25 \%$ compared to current, Grassi et al., 2017). Although, close to half of these emissions would still be compensated by the net ocean and land sinks, assuming that their sink efficiency will not decline (Fig. 2B), it would take a much stronger land carbon sink enhancement to compensate for the atmospheric $\mathrm{CO}_{2}$ growth.

To explore the maximum level of land sink enhancement that could be possible within a few decades, relevant for the NDCs targets, we detail below a scenario combining the technical potential of SOC sequestration and the contribution of $\mathrm{C}$ storage in above-ground forest biomass (Table 2, Fig. 2C). For croplands and grazing lands (excluding bioenergy), the mean global SOC sequestration technical potential by 2030 was estimated at $1.4 \mathrm{GtC}$ per year averaged over $0-30 \mathrm{~cm}$ (Smith et al., 2008) based on integrated impacts of changes in agricultural practices over the top $30 \mathrm{~cm}$ of the soil profile (reviewed by Ogle et al., 2005). Unfortunately, the integrated impacts of changes in agricultural practices have not yet been estimated over depths greater than $30 \mathrm{~cm}$ of the soil profile.

This potential is equivalent to a relative annual SOC stock growth rate of $0.6 \%$, slightly higher than the 4 per 1000 target, when calculated by reference to a global agricultural SOC stock of $233 \mathrm{GtC}$, as estimated over $0-30 \mathrm{~cm}$ from biome areas and SOC stocks by depth (see Jobbágy and Jackson, 2000). The relatively high technical potential in agricultural soils, compared to other lands uses, is likely to be related to SOC depletion, since conversion from natural to agricultural ecosystems has generally resulted in a significant loss of SOC (up to 50\%) (Lal, 2010).

It includes restoring low water tables organic soils that are now under cultivation, but barely considers the potential for expanding agroforestry $\left(0.01 \mathrm{GtC} \cdot \mathrm{y}^{-1}\right)$ and considers only a small potential $\left(0.16 \mathrm{GtC} \cdot \mathrm{y}^{-1}\right)$ for the restoration of desertified and salinized land. Below, we argue why these two options may in fact have a higher potential.

Recently, it was shown that $43 \%$ of global agricultural land has at least $10 \%$ tree cover and that the tree cover has increased by $2 \%$ over the last 10 years, resulting in additional annual $\mathrm{C}$ storage of at least $0.2 \mathrm{GtC} \cdot \mathrm{y}^{-1}$ (Zomer et al., 2016). Given the large amount of agricultural land potentially suitable for increasing tree cover density, agroforestry 

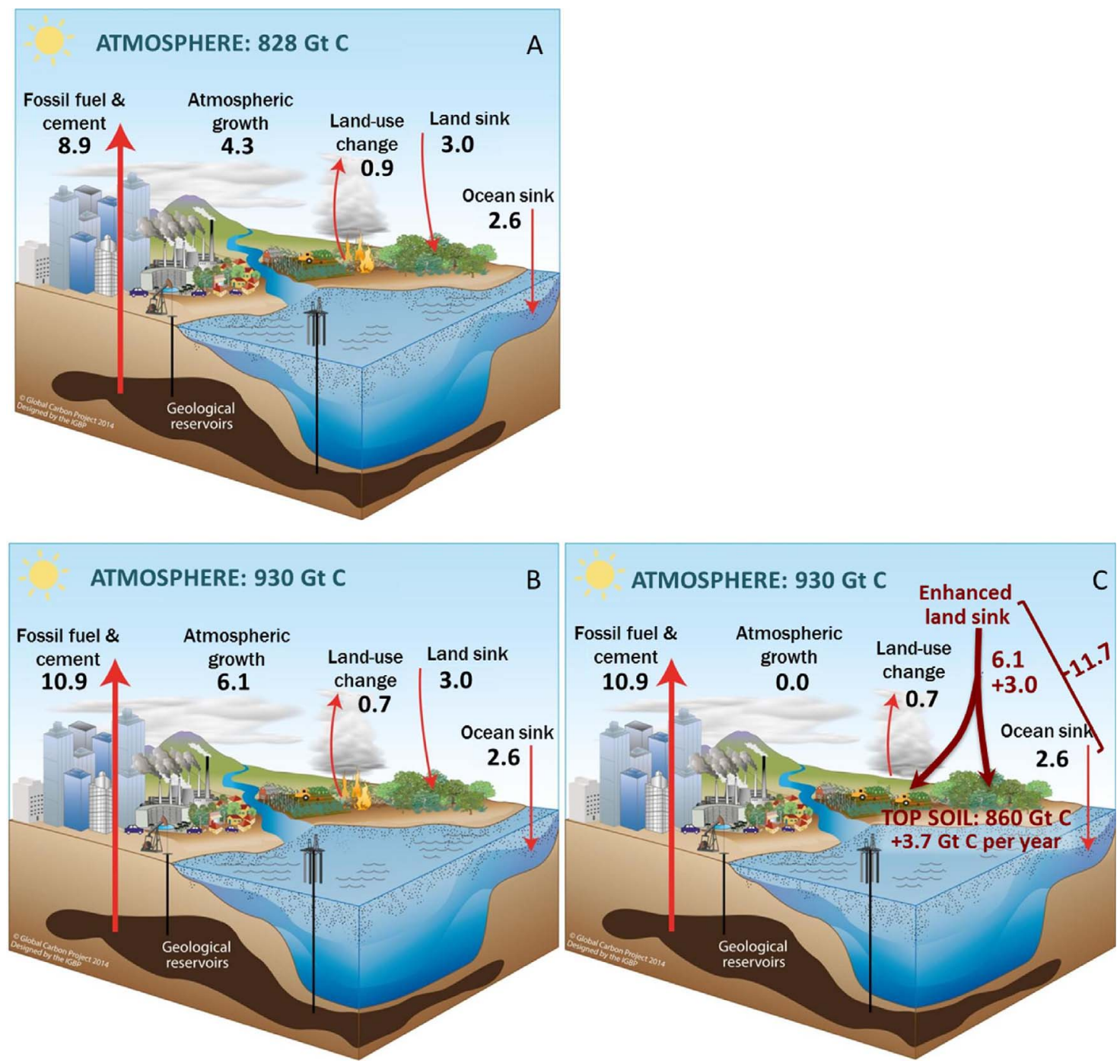

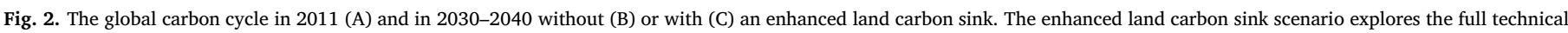

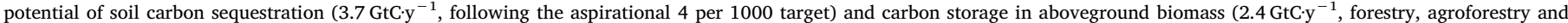

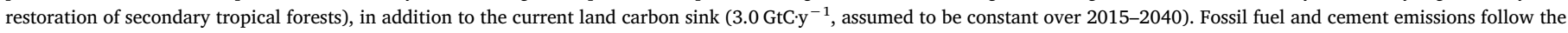

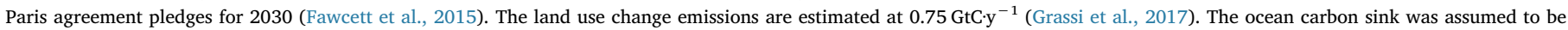
constant over 2011-2040. Modified after Le Quéré et al. (2015).

or additional tree planting in agricultural areas has a potential to sequester $\mathrm{C}$ while simultaneously enhancing food security (Lorenz and Lal, 2014; Lipper et al., 2014). Agroforestry is currently developed over roughly 820 million ha (Mha) of agricultural land, that is 20 and $15 \%$ of global croplands and grasslands, respectively, not including 200 Mha of forests managed as agro-forests (Nair et al., 2009). In the scenario proposed in Table 2, we assume its expansion over an additional 320 Mha of agricultural land (6\% of global agricultural land).

Restoration of salt-affected lands and desertification control could add $0.5-1.4 \mathrm{GtC} \cdot \mathrm{y}^{-1}$ (Lal, 2010). The Land Degradation Neutrality Fund Global Mechanism of the United Nations Convention to Combat Desertification (UNCCD) targets in the next 20 years the rehabilitation of 300 Mha of this land use type, which would create a carbon sink of 0.27 GtC $\cdot y^{-1}$ (UNCCD Global Mechanism, 2017). Consistently with the 4 per 1000 target, we assume here that accelerated land rehabilitation could take place and use a potential SOC sequestration value of $0.9 \mathrm{GtC} \cdot \mathrm{y}^{-1}$ with this option (Table 2).

Two additional options for SOC sequestration in the agriculture sector have been recently highlighted by Paustian et al. (2016): biochar and the use of deep rooted crops, through enhanced plant phenotypes. Both options could be used on large agricultural land areas (above
$1000 \mathrm{Mha}$ ) and could bring a total of $0.76 \mathrm{GtC} \cdot \mathrm{y}^{-1}$ of potential SOC sequestration (Paustian et al., 2016). Nevertheless, these novel options may not be mature enough for reaching full potential within a few decades and are thus considered here (Table 2) at half their potential value.

Biochar is charcoal produced through pyrolysis under controlled temperature and low oxygen environment, and generally characterized by a fine texture, which could mineralize 10-100 times more slowly than uncharred biomass, though these estimates are still debated (Schmidt et al., 2011; Lutfalla et al., 2017). However, reductions in crop yields have been reported in some instances after biochar addition, and long-term effects on soil fertility are largely unknown. Additionally, compared with un-amended soils, gaseous emissions from biocharamended soils have been reported for methane and nitrous oxide (Mukherjee and Lal, 2014). Net life-cycle emissions largely depend on whether the biomass used for biochar would have otherwise been burnt, added to a landfill or left in place as living biomass (DeLonge et al., 2013).

Breeding for deep-rooted crops may also pose significant challenges. The rise in crop harvest index obtained from selecting plants with decreased allocation to roots and higher allocation to grain, is considered 
Table 2

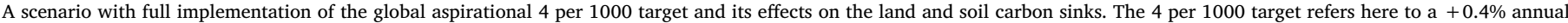
growth rate in SOC stock over a reference soil depth of $0-40 \mathrm{~cm}$.

\begin{tabular}{|c|c|c|c|c|c|c|c|}
\hline \multicolumn{4}{|c|}{ A. Baseline atmospheric carbon balance following conditional NDCs } & $\mathrm{GtC} \cdot \mathrm{y}^{-1}$ & Literature source & \multicolumn{2}{|l|}{ Comments } \\
\hline \multicolumn{4}{|c|}{ Emissions from fossil fuels and cement } & 10.9 & \multicolumn{3}{|l|}{ Fawcett et al. (2015) } \\
\hline \multicolumn{4}{|c|}{ Land carbon sink } & -3.0 & Le Quéré et al. (2015) & \multicolumn{2}{|c|}{ Assumed to be constant until the 2030 's } \\
\hline Ocean carbon sink & & & & \multirow{2}{*}{$\begin{array}{l}-2.6 \\
0.76\end{array}$} & Le Quéré et al. (2015) & & \\
\hline \multicolumn{4}{|c|}{ Emissions from net land use change (tropical deforestation) } & & Grassi et al. (2017) & \multicolumn{2}{|c|}{ Terrestrial carbon $\left(\mathrm{CO}_{2}\right)$ source } \\
\hline \multirow[t]{2}{*}{ B. Land carbon storage scenario } & Biomass & SOC & Literature so & & \multirow{2}{*}{\multicolumn{2}{|c|}{ Comments }} & Literature range \\
\hline & \multicolumn{4}{|l|}{$\mathrm{GtC} \cdot \mathrm{y}^{-1}$} & & & $\mathrm{GtC} \cdot \mathrm{y}^{-1}$ \\
\hline $\begin{array}{l}\text { Agriculture (croplands, } \\
\text { grasslands) }\end{array}$ & 0.0 & -1.4 & \multicolumn{2}{|c|}{$\begin{array}{l}\text { Smith et al. (2008); Lal (2010); } \\
\text { Paustian et al. (2016) }\end{array}$} & \multicolumn{2}{|c|}{$\begin{array}{l}\text { Changes in agricultural practices (excluding: restoration of } \\
\text { degraded lands and agroforestry, see below) }\end{array}$} & $-1.8-1.4$ \\
\hline Biochar & 0.0 & -0.3 & \multicolumn{2}{|c|}{ Paustian et al. (2016) } & & & -0.49 \\
\hline $\begin{array}{l}\text { Enhanced root phenotypes (deep } \\
\text { roots) }\end{array}$ & 0.0 & -0.2 & \multicolumn{2}{|c|}{ Paustian et al. (2016) } & & & -0.27 \\
\hline Agroforestry & -0.6 & -0.2 & \multicolumn{2}{|c|}{ IPCC (2000); Nair et al. (2009) } & \multicolumn{2}{|l|}{ Agroforestry over 320 Mha } & $-1.0-0.2$ \\
\hline Salinized and desertified land & 0.0 & -0.7 & \multicolumn{2}{|c|}{ Lal (2010) } & \multicolumn{2}{|c|}{ Restoration of degraded lands } & $-1.4-0.5$ \\
\hline Secondary forest regrowth & -1.0 & -0.5 & \multicolumn{2}{|c|}{ Houghton et al. (2015) } & \multicolumn{2}{|c|}{$\begin{array}{l}\text { Reducing emissions from harvests and re-clearing of fallows in } \\
\text { secondary tropical forests }\end{array}$} & -3.0 \\
\hline Reforestation & -0.8 & -0.4 & \multicolumn{2}{|c|}{$\begin{array}{l}\text { Smith et al. (2016); Houghton et al. } \\
\text { (2015) }\end{array}$} & \multicolumn{2}{|c|}{$\begin{array}{l}\text { Reforestation over } 280 \text { Mha of degraded pastures and marginal } \\
\text { lands, mainly in tropical regions }\end{array}$} & $-1.2-1.0$ \\
\hline Additional land carbon sink & -2.4 & -3.7 & & & & & \\
\hline Total additional land carbon sink & -6.1 & & & & & & \\
\hline Net land carbon sink $\left(\mathrm{GtC} \cdot \mathrm{y}^{-1}\right)$ & -8.3 & & & & & & \\
\hline Net atmospheric flux (GtC $\cdot y^{-1}$ ) & 0.0 & & & & & & \\
\hline
\end{tabular}

as one of the main levers of the sustained increase in cereal crop yields over the last decades. In modern cereal crop varieties, approximately half of the total plant biomass is harvested as grains, whereas with old varieties only one third of biomass contributes to grain yields (Sinclair, 1998). Therefore, partitioning more dry-matter to deep roots could reduce yields and crop nutrients uptake if rooting density is reduced in the top soil. However, going for more deep-rooted crops would have the advantage of a better resistance to drought stress and should not be ignored as an option. Breeding for deep roots is a current objective for several important crops, e.g. cotton (Lacape et al., 2016).

$44 \%$ of the C stock of world's forests is ascribed to soils (Pan et al., 2011) and, on average, one-third of the photosynthetic $C$ is estimated to be partitioned below-ground in forests (Campioli et al., 2015). Houghton et al. (2015) have underlined that secondary forest regrowth in the tropics could play a large role in stabilizing atmospheric $\mathrm{CO}_{2}$. These authors estimate that carbon is currently accumulating in secondary forests recovering from harvests and from past slash and burn agriculture at rates as high as $3 \mathrm{GtC} \cdot \mathrm{y}^{-1}$. If $\mathrm{C}$ emissions associated to harvests and re-clearing of fallows were stopped, this accumulation rate could last for decades. The restoration of degraded tropical forests is supported by the Bonn Challenge (The Bonn Challenge, 2017), which has a global goal to restore 150 Mha of deforested and degraded land by 2020 , consistent with the 161.6 Mha of COP21 NDC pledges on reforestation, afforestation and restoration of forests. However, to avoid possible double counting with the current land C sink $\left(3.0 \mathrm{GtC} \cdot \mathrm{y}^{-1}\right)$, we use a net accumulation rate of $1.5 \mathrm{GtC} \cdot \mathrm{y}^{-1}$ for the restoration of degraded forests, with one third of the $\mathrm{C}$ being partitioned below-ground (Table 2).

A potential of $1 \mathrm{GtC} \cdot \mathrm{y}^{-1}$ for net sequestration of $\mathrm{C}$ through afforestation, reforestation, forest restoration and improved forest management was estimated by Nabuurs et al. (2007). Reforestation comes with large land requirements (Houghton et al., 2015; Smith et al., 2013) and with risks of displacing agricultural production, thereby inducing deforestation. Afforestation, especially at high latitude, would change albedo, weakening the cooling effect of increased carbon stocks (Smith et al., 2016). Values considered in the scenario (Table 2) assume a reforestation (on $280 \mathrm{Mha}$ ) which is in the upper range of afforested areas used in bioenergy scenarios by 2050 for a $2{ }^{\circ} \mathrm{C}$ scenario (Popp et al., 2017) and would take place on previously forested degraded pastures or marginal lands and not at high latitude.

Therefore, this technical potential scenario suggests that the land carbon sink could be enhanced by up to $6.1 \mathrm{GtC} \cdot \mathrm{y}^{-1}$, of which $60 \%$ could take place as SOC sequestration (Table 2). With this enhancement, the net land $\mathrm{C}$ sink would in theory reach $8.3 \mathrm{GtC} \cdot \mathrm{y}^{-1}$, thereby compensating, together with the ocean sink, the atmospheric growth of $\mathrm{CO}_{2}$ after 2030 or 2040 . This optimistic scenario, which combines forests (Houghton et al., 2015; Nabuurs et al., 2007) and soil (Lal, 2010; Smith et al., 2013) carbon sequestration technical potentials, would therefore allow for an early offsetting of anthropogenic $\mathrm{CO}_{2}$ emissions (Table 2 and Fig. 2). This scenario is, however, at the limits of global technical potential and should be considered as implausible when considering adoption constraints and socio-economic barriers (see Section 3.5). Nevertheless, it shows that the full technical potential of the 4 per 1000 target for soils requires considering forestry and agroforestry options which add a large above-ground $\mathrm{C}$ storage component and can contribute later in the century to bioenergy production. It also reinforces the conclusion that the restoration of the biosphere should happen in concert with the phasing out of fossil fuels to avoid hazardous climate change.

\subsection{Permanence of SOC, adoption constraints and socio-economic barriers}

One of the questions which remains after having estimated the technical potential from the available literature relates to the permanence of SOC stocks, and to the feasibility of implementing the global 4 per 1000 target in a relatively short time and in contrasted social and economic environments.

As shown by radiocarbon studies, the mean age of SOC is of several millennia (3100 \pm 1800 years over $1 \mathrm{~m}$ depth, He et al., 2016). Most of the SOC turns over relatively slowly, within decades and centuries (at least). Nevertheless, some SOC turns over more quickly, on time scales ranging from days to decades. This more labile SOC feeds the SOC that turns over more slowly, and is influenced by soil management practices, since it predominantly originates from plant litter and root exudates, and from animal and microbial residues (Dignac et al., 2017). The extra soil C accumulating is partly in unprotected forms (i.e. labile pool) and the size of this pool cannot be maintained without continuous supply of organic matter to the soil. Moreover, the amount of $\mathrm{C}$ that can be 
stabilized in a given soil layer (i.e. slow pool) is often viewed as limited by a saturation potential of clays and silt (Feng et al., 2013; Powlson et al., 2014; Six et al., 2002).

Nevertheless, below-ground $\mathrm{C}$ stocks are less vulnerable to disturbances than the above-ground $\mathrm{C}$ and, compared to afforestation, their enhancement can be achieved without large land requirements. However, reaping the climate benefits of SOC sequestration requires an understanding that: i) SOC will increase only over a finite period, up to the point when a new SOC steady-state is approached (Sommer and Bossio, 2014), ii) the additional SOC stock will need to be monitored and preserved by adapting land management practices to climate change.

In agricultural lands, the temporal dynamics of SOC stock changes will be constrained by the adoption rate and by the long-term maintenance of improved land management practices. Practical limitations are, in part, reflected by economic potential calculations. For example, according to mitigation marginal abatement cost curves, 47, 65 and $86 \%$ of the technical potential for SOC sequestration in agricultural (croplands and grasslands) soils would be reached at costs of 20,50 and 100 USD per $\mathrm{tCO}_{2}$, respectively (Smith et al., 2008).

At the global scale, if agricultural SOC sequestration options were incentivized, the cost-effective contribution of the agriculture, forestry and land use (AFOLU) sector to achieve the goals of the Paris Agreement on Climate, including $\mathrm{N}_{2} \mathrm{O}$ and $\mathrm{CH}_{4}$ mitigation, is up to $3.1 \mathrm{GtCO}_{2}-\mathrm{C}$ eq.y ${ }^{-1}$ by 2050 (Frank et al., 2017). For croplands, the economic potential could reach $62 \%$ of the technical potential with a price of 100 USD per $\mathrm{tCO}_{2}$ (Smith et al., 2008), their scenario being compatible with keeping global warming below $2^{\circ} \mathrm{C}$ by 2100 (radiative forcing of $2.6 \mathrm{~W} \cdot \mathrm{m}^{-2}$ ), but not below $1.5^{\circ} \mathrm{C}$ (radiative forcing of $1.9 \mathrm{~W} \cdot \mathrm{m}^{-2}$, compatible with a price of $190 \mathrm{USD}$ per $\mathrm{tCO}_{2}$ ) (Frank et al., 2017). Therefore, if the $\mathrm{CO}_{2}$ price remains below 100 USD per $\mathrm{tCO}_{2}$, less than two thirds of croplands (i.e. 850 Mha assuming a constant total arable land use) could be converted to SOC sequestration-enhancing practices.

One important question is how long it may take to reach the ceiling economic potential. Recent trends in the sector, such as the global adoption of conservation agriculture (CA) show that large-scale changes can occur at decadal scale: within 12 years, CA area increased from 45 Mha in 1999 up to 125 Mha in 2011 across all continents, including both small and large farms (Derpsch et al., 2010; Dumanski and Peiretti, 2013). Similarly, tree cover on agricultural land has increased by $2 \%$ over the last 10 years (Zomer et al., 2016).

This illustrates the rapid recent development $(+8.9 \%$ area growth per year) during the last decade of agricultural practices contributing to soil conservation. If this historical relative growth rate was applicable to the future adoption of SOC sequestration practices, the ceiling area (corresponding to an economic potential of 850 Mha for improved cropland management practices) could be reached before 2030 (Fig. 3). Even assuming a lower adoption rate $(+5 \%$ area per year), an economic potential corresponding to 850 Mha under agricultural practices enhancing SOC sequestration would be reached before 2050 (Fig. 3).

Nevertheless, part of the cropland area having adopted practices enhancing SOC sequestration could revert after some decades to land degrading practices. For instance there has been large dis-adoption of CA in sub-Saharan Africa (Giller et al., 2009). If dis-adoption happened, on average, after 50 years (i.e. average annual drop-out rate of $1.4 \%$ per year, see Materials and Methods section), the ceiling area corresponding to the economic potential would be reached in the mid 2030's for the historical adoption rate (8.9\% per year) and in the mid 2060's for the reduced adoption rate (5\% per year) (Fig. 3).

These simple calculations show that the adoption rate of improved practices (Sommer and Bossio, 2014) and the duration during which these practices will be maintained are critical for the impacts of action plans implementing the 4 per 1000 target. Adoption constraints, costs and numerous trade-offs across mitigation options strongly reduce the economic potential of management alternatives compared to what is

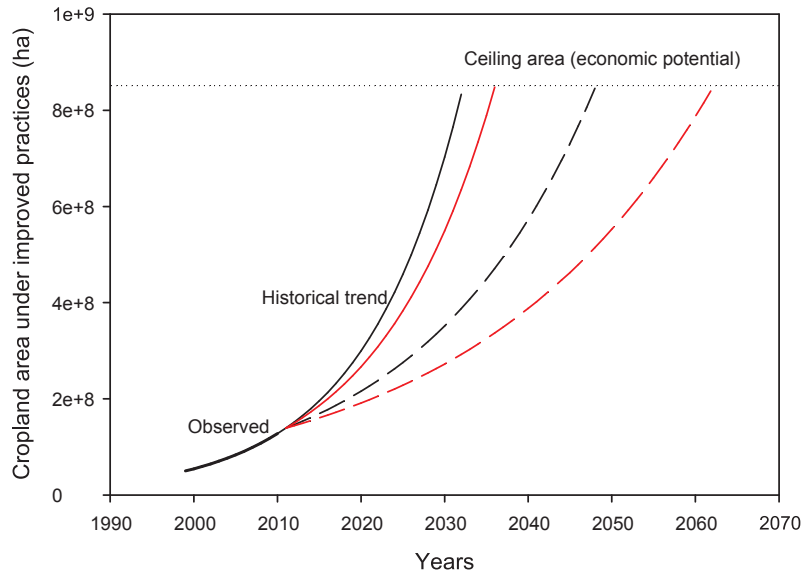

Fig. 3. Historical trend in the expansion of cropland area under conservation agriculture (1999-2011) and projected trends assuming similar (solid lines, 8.9\%) or reduced (dashed lines, 5\%) annual relative adoption rate, with permanent improved practices (black) and with an average 50-year duration of the improved practices before drop-out (i.e. $1.4 \%$ annual relative drop-out rate) (red). (For interpretation of the references to colour in this figure legend, the reader is referred to the web version of this article.)

technically possible (Smith et al., 2016; Herrero et al., 2016).

Nevertheless, consistent policy options may increase adoption and raise the economic potential, e.g. in the livestock sector (Gerber et al., 2013). SOC sequestration policies can increase the value of C-enhancing production systems by paying farmers for the provided $\mathrm{C}$ sink, and thus allow for more agricultural land to remain in production, in turn benefitting food production (Frank et al., 2017). However, whether C offset schemes and similar policies can provide sufficiently high incentives that can be maintained over enough years to support agricultural practices that preserve increased SOC stocks in agriculture while protecting existing legitimate land rights, remains an open question. In this respect, it should be noted that agricultural subsidies in the top 21 foodproducing countries, responsible for almost $80 \%$ of global agricultural value added in the world, are estimated to amount to 486 billion USD in 2012 (Worldwatch Institute, 2017). With a $\mathrm{CO}_{2}$ price of 100 USD per $\mathrm{tCO}_{2}$, fully implementing the technical potential of the 4 per 1000 initiative on croplands and grasslands via agricultural subsidies would require a total budget representing less than $30 \%$ of these agricultural subsidies, which shows the potential to value SOC sequestration in agricultural food supply chains. The total number of farms would reach 460 million in 111 countries, with $72 \%$ of farms of less than one hectare ( $24 \%$ of the total agricultural area), while farms over 20 ha are dominant in terms of agricultural land area ( $42 \%$ of the total) (Lowder et al., 2014). These numbers illustrate the major social dimension of agriculture and the opportunity to preserve, or even develop, rural employment especially with smallholders through soil conservation and restoration actions implementing the 4 per 1000 target.

However, the preliminary work on economic potentials presented here is not the only driver for effective soil carbon sequestration and for the adoption of relevant management practices: additional studies are needed to refine and improve our understanding of the conditions which foster or perpetuate sustainable practices, i.e. the enabling environment for soil carbon sequestration. This enabling environment can be refined and strengthened, inter alia, via an analysis of situations where effective governance, institutional and organizational arrangements, public policies, including financial mechanisms, incentive and regulatory instruments have allowed to promote, perpetuate and reward relevant sustainable practices. Specific challenges relate to short term, near term and long term effects, including the risk of reversibility of practices and negative direct or indirect side effects of practices at different scales on relevant sustainable development goals. 


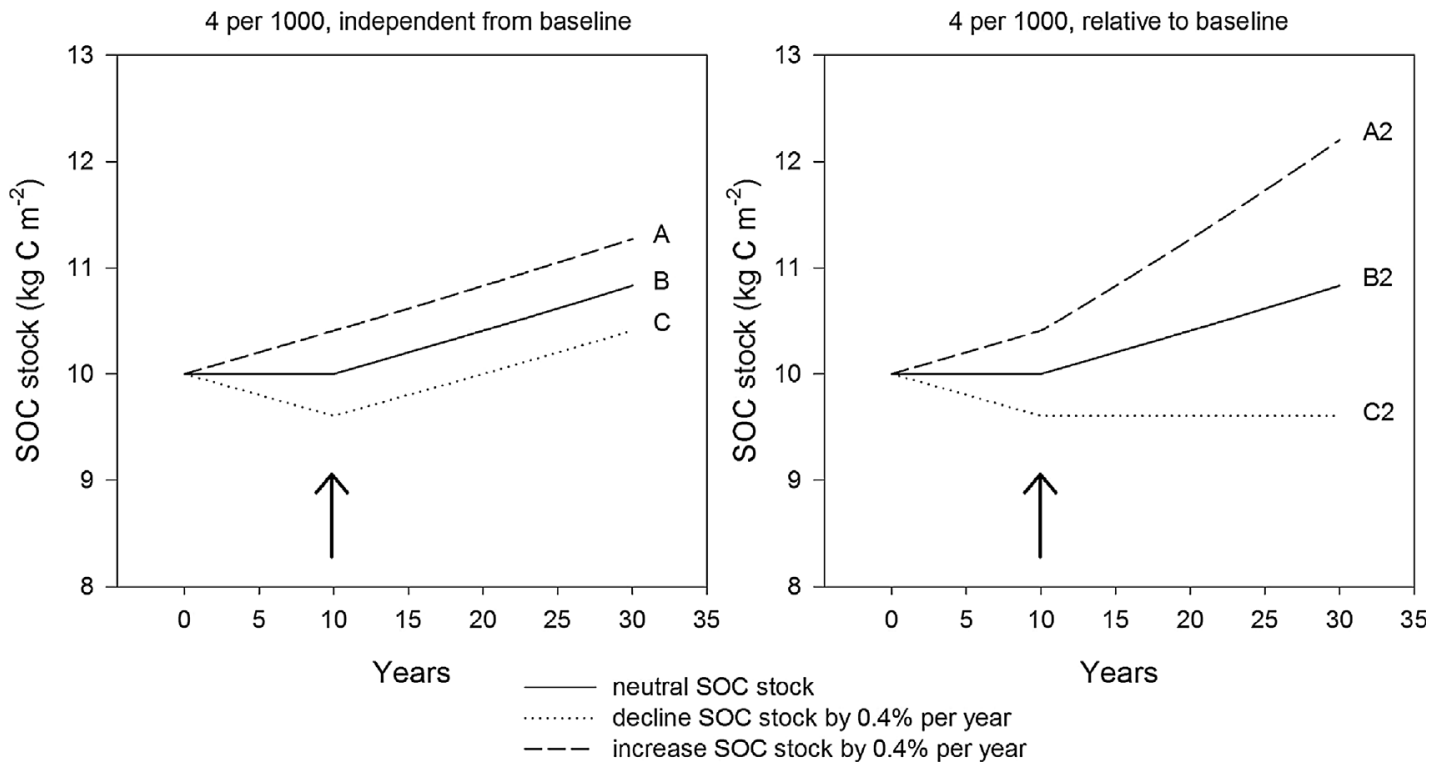

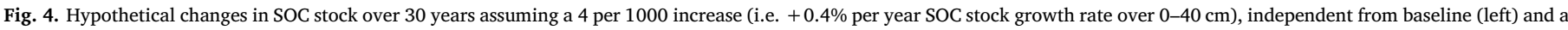

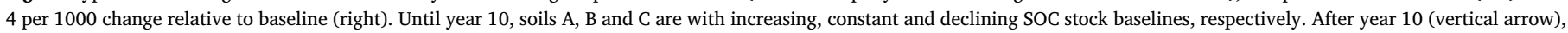
all SOC stocks increase at $+0.4 \%$ per year (left), or all SOC stocks change by $+0.4 \%$ per year relative to their baseline (right).

\subsection{Spatial scale and baseline issues for the local implementation of the 4 per 1000 aspirational target}

Long-term agricultural studies investigating SOC stock changes were often restricted to the top soil (e.g. 0-20, or 0-30 cm), although an increasing number of studies show subsoil SOC stock changes in response to changes in land use and in agricultural management practices (Ward et al., 2016). In practice, for monitoring if intended SOC increases are effectively realized, SOC stock relative growth rates would need to be directly estimated from top (e.g. $0-30 \mathrm{~cm}$ or $0-40 \mathrm{~cm}$ ) soil samples and checked with deep soil samples.

Some soils keep a rather constant SOC stock over decades, while others may degrade leading to SOC stock decline, or build-up SOC after improved practices (FAO and ITPS, 2015; Minasny et al., 2017). Under such contrasted conditions, should the 4 per 1000 aspirational target be considered as a fixed increase rate, or as a differential increase compared to a baseline? In Fig. 4, we consider three hypothetical baselines (A, increasing by $0.4 \%$ per year, B, neutral, C, declining by $0.4 \%$ per year) for SOC. Implementing a 4 per 1000 target which is independent from the baseline requires establishing in all soils a relative annual increase by $+0.4 \%$. With this assumption, no change would be required for soil A, soil B would have to shift by $+0.4 \%$ per year compared to its neutral SOC baseline and soil C by $+0.8 \%$ per year compared to its declining SOC baseline (Fig. 4). This would result in soil management targets requiring stringent changes with degrading soils and, in contrast, no change when SOC already builds up at rates already higher or equal to $0.4 \%$ per year. In contrast, implementing a 4 per 1000 target relative to the baseline implies SOC stocks would all shift by $+0.4 \%$ per year compared to their baseline, resulting in $+0.8,+0.4$ and $0 \%$ annual increase rates for soils A, B and C, respectively (Fig. 4, A2, B2, C2).

These hypothetical implementation cases would provide an averaged SOC stock growth by $+0.4 \%$ per year, thereby matching the 4 per 1000 target criterion. However, the effort sharing between degrading and accruing soils would differ between the two cases. In the first case (target independent from the baseline) the magnitude of the effort would be higher for soils initially degrading (reversal from a loss of $-0.4 \%$ per year to a gain of $+0.4 \%$ per year) than for accruing soils (no change) (Fig. 4). This would result in a strong priority being set on the rehabilitation of degrading land, in agreement with the land degradation neutrality (LDN) objective of the UNCCD, and there would be no enrolment in 4 per 1000 projects of land with already accruing SOC stocks at averaged rates equal or higher than $0.4 \%$ per year.

In contrast, in the second case (target relative to the baseline), efforts would be equally shared across the three example soils (Fig. 4) and the accruing soil (A) would need to reach an even higher SOC sequestration rate $(+0.8 \%$ per year). With this case (target relative to the baseline), virtually all land would need to be enrolled in 4 per 1000 projects to achieve the global target potential. Since no priority would be set on degrading lands, this option would not be consistent with the LDN objective of the UNCCD.

This example illustrates some of the challenges associated with the implementation of the 4 per 1000 target and questions the spatial scales over which this aspirational target could be used. The LDN is defined as 'a state whereby the amount and quality of land resource necessary to support ecosystem functions and services and enhance food security, remains stable or increases within specified temporal and spatial scales and ecosystems' (Orr et al., 2017). This definition helps in showing that a given spatial unit, including one or more ecosystem types, needs to be defined when targeting the local implementation of the global 4 per 1000 aspirational target. To be consistent with this target, actions taken to increase SOC stock in the spatial unit should aim at an average relative growth rate of SOC stock by at least $+0.4 \%$ per year over at least $0-30 \mathrm{~cm}$ soil depth and, if possible, down to 30 or $40 \mathrm{~cm}$. For the sake of consistency with the LDN principle and in agreement with findings showing that degraded soils have more potential for SOC sequestration (Minasny et al., 2017), priority could initially be given to the rehabilitation of degraded lands (i.e. 4 per 1000 target independent from the baseline). In a later stage, the relative to baseline 4 per 1000 target could be used, through the use of technologies that could raise SOC stock growth rate above $0.4 \%$ per year (e.g. Fig. 4A2).

\subsection{Non- $\mathrm{CO}_{2}$ GHG emissions and nutrients cycling}

SOC sequestration options affect agricultural $\mathrm{N}_{2} \mathrm{O}$ and $\mathrm{CH}_{4}$ emissions. The case of no-till compared to conventional tillage is an example of the interplay between these factors, since during the first years after adoption of no-till, $\mathrm{N}_{2} \mathrm{O}$ emissions generally increase (van Kessel et al., 2013). The effectiveness of no-till and CA can, however, be enhanced by adopting a system-based approach (Lal, 2016).

With grazing systems, restoration of degraded pastures increases 
SOM content (Assad et al., 2013) but may also leads to higher $\mathrm{N}$ fertilizer applications and to higher animal stocking density, hence, increasing $\mathrm{N}_{2} \mathrm{O}$ and enteric methane emissions per unit area. It is still unclear whether increasing beef production through pasture intensification could lower GHG emissions in Brazil by avoiding deforestation (Barioni et al., 2017; de Oliveira Silva et al., 2016; Phalan et al., 2016).

Within terrestrial ecosystems, the $\mathrm{C}, \mathrm{N}$ and $\mathrm{P}$ cycles are strongly coupled by the elemental stoichiometry characterizing both plant autotrophy and soil microbial heterotrophy (Soussana and Lemaire, 2014). The elemental C:N and C:P ratios of SOM vary little and are close to 12 and 50, respectively (Kirkby et al., 2011). The build-up of SOC in some productive agricultural soils is often much less than expected from the amounts of C-rich residues returned to them because optimum C sequestration may require additional nutrients above that required for crop production alone (Kirkby et al., 2014). Therefore, C sequestration may require an additional immobilization of nitrogen and phosphorus in SOM, which may question the feasibility, costs and environmental consequences of SOC sequestration (van Groenigen et al., 2017).

In this discussion, it is important to note the large impact of soil erosion on the nutrients balance of agricultural lands. Although the global net $\mathrm{C}$ balance of erosion processes is highly uncertain and has been estimated to be a net C sink (Wang et al., 2017), when erosion occurs at site scale, it represents a carbon loss which can induce serious yield and fertility losses and which thus needs to be limited. Soil erosion by water induces annual losses of 23-42 Mt (megaton) N and 15-26 Mt $\mathrm{P}$ in agricultural land (FAO and ITPS, 2015). These nutrients losses, which are of the same order of magnitude than annual fertilizer application rates (ca. $112 \mathrm{Mt}$ of $\mathrm{N}$ and ca. $18 \mathrm{Mt}$ of P, FAO and ITPS, 2015), need to be replaced. Several options can be considered for replacing lost nutrients, among which the addition of fertilizers. However, fertilization can only be done at an economic cost which is too high in poor regions such as sub-Saharan Africa. As a consequence, the removal of nutrients by erosion from agricultural fields is much higher than the amount of fertilizer applied. Limiting erosion and land degradation could therefore preserve a source of nutrients both for plants and for the build-up of SOM and at global scale would reduce the needs for additional fertilizer inputs (Table 3 ).

The 4 per 1000 target provides a guideline for locally increasing

Table 3

Global mean and standard deviation of annual SOC sequestration at a rate of $0.4 \%$ per year (4 per 1000) and of N, P and S additional soil immobilization assuming C:N, C:P and C:S elemental ratios of 12, 50 and 71 (Kirkby et al., 2011), respectively. Estimated N, P and S fertilizer costs are calculated per ton SOC (updated from Kirkby et al., 2011, source WorldBank, 2017) and per hectare, in a scenario based on a strong assumption: all nutrients immobilized to reach the 4 per 1000 SOC sequestration rate in croplands come from mineral fertilizers applications. This simple calculation shows that relying on inorganic fertilizers only would be, in most cases, too expensive to achieve the 4 per 1000 SOC sequestration target. Note that the mean estimate for annual $\mathrm{N}$ and $\mathrm{P}$ losses by erosion in agricultural lands reaches $6.6 \mathrm{kgN} \cdot \mathrm{ha}^{-1}$ and $4.2 \mathrm{kgP} \cdot \mathrm{ha}^{-1}$ (FAO and ITPS, 2015). The mean SOC stock of global croplands is estimated over $0-40 \mathrm{~cm}$ depth at 52.0 $\mathrm{tC} \cdot \mathrm{ha}^{-1}$ with a standard deviation of $30 \mathrm{tC}^{-1} \mathrm{ha}^{-1}$ (source: Harmonized World Soil Map, www.fao.org/soils-portal/soil-survey/soil-maps-and-databases/harmonized-world-soildatabase-v12/en/www.fao.org/soils-portal/soil-survey/soil-maps-and-databases/ harmonized-world-soil-database-v12/en/, Accessed May 14, 2017).

\begin{tabular}{|c|c|c|c|c|}
\hline C, N, P and S fluxes & Mean & s.d. & $\begin{array}{l}\text { Fertilizer price } \\
\text { (USD per } \mathrm{t} \text { SOC) }\end{array}$ & $\begin{array}{l}\text { Fertilizer price } \\
\left(\text { USD.ha }^{-1}\right)\end{array}$ \\
\hline $\begin{array}{l}0.4 \% \text { annual SOC } \\
\text { sequestration } \\
\left(\mathrm{kgC} \mathrm{ha}^{-1} \cdot \mathrm{y}^{-1}\right)\end{array}$ & 208 & 156 & - & \\
\hline $\begin{array}{l}\text { Additional } \mathrm{N} \\
\text { immobilization } \\
\quad\left(\mathrm{kgN} \cdot \mathrm{ha}^{-1} \cdot \mathrm{y}^{-1}\right)\end{array}$ & 17.3 & 13.0 & 121 & 25 \\
\hline $\begin{array}{l}\text { Additional P immobilization } \\
\qquad\left(\mathrm{kgP} \cdot \mathrm{ha}^{-1} \cdot \mathrm{y}^{-1}\right)\end{array}$ & 4.2 & 3.1 & 27 & 5.7 \\
\hline $\begin{array}{l}\text { Additional S immobilization } \\
\qquad\left(\mathrm{kgS} \cdot \mathrm{ha}^{-1} \cdot \mathrm{y}^{-1}\right)\end{array}$ & 2.9 & 2.2 & 20 & 4.1 \\
\hline
\end{tabular}

SOC stocks. With this aspirational target, degraded soils with low fertility and low SOC stocks need to immobilize less $\mathrm{N}$ and $\mathrm{P}$ than soils rich in organic matter. For instance, with an initial SOC stock of $20 \mathrm{tC} \cdot \mathrm{ha}^{-1}$, 7 and $1.6 \mathrm{~kg} \mathrm{~N}$ and $\mathrm{P}$ per hectare per year would need to be immobilized. In contrast, for an initial SOC stock of $80 \mathrm{tC} \cdot \mathrm{ha}^{-1}$ soil nutrients immobilization would reach 28 and $6.4 \mathrm{~kg} \mathrm{~N}$ and $\mathrm{P}$ per hectare per year. Reactive $\mathrm{N}(\mathrm{Nr})$ availability in agricultural ecosystems is large (ca. $300 \mathrm{MtNr} \cdot \mathrm{y}^{-1}$; Ciais et al., 2013), but it is unevenly distributed. In some agricultural regions, since there is excess supply of reactive $\mathrm{N}$ to croplands, additional soil $\mathrm{N}$ immobilization through SOC sequestration could reduce environmental pollution without harming crop yields (e.g. in China, van Groenigen et al., 2017).

In contrast, in extensive agricultural and forestry systems, $\mathrm{Nr}$ and $\mathrm{P}$ availabilities may limit SOC sequestration. The mean SOC stock of the world's croplands is $52 \mathrm{tC} \cdot \mathrm{ha}^{-1}$ over $0-40 \mathrm{~cm}$ depth, leading to a mean aspirational 4 per 1000 annual SOC sequestration target of $208 \mathrm{kgC} \cdot \mathrm{ha}^{-1} \cdot \mathrm{y}^{-1}$ (Table 3 ). If, among the different options available to provide immobilization of $\mathrm{Nr}, \mathrm{P}$ and Sulphur (S) in soils, only fertilizer applications were considered, the annual cost of the required fertilizers would reach approximately 37 USD per hectare, that is 177 USD per ton of $\mathrm{C}$ sequestered (48 USD per $\mathrm{tCO}_{2}$ ) (Table 3). Therefore, inorganic fertilizers would be, in most cases, too expensive to achieve the 4 per 1000 SOC sequestration target, although a limited use of inorganic fertilizers may be needed in some regions and some systems. In addition, the recycling of organic fertilizers derived from livestock or from urban wastes (Chabbi et al., 2017) could be used to counter N and P deficiencies, provided that over-fertilization is avoided.

Beyond erosion limitation at local scale and sustainable fertilizer applications, an increased use of biological $\mathrm{N}$ fixation by legumes in cropping and grazing systems has a large potential to overcome $\mathrm{N}$ limitation, while bringing additional benefits for climate change adaptation (Lipper et al., 2014; Lüscher et al., 2014). Phosphorus availability is likely to limit biological $\mathrm{N}$ fixation in some soils, but symbiotic $\mathrm{N}_{2}$ fixation plants possess an advantage in phosphorus acquisition especially in warm climates, e.g. through root phosphatase (Houlton et al., 2008). In the long term, since the global N:P stoichiometry is increasing under human influence (Peñuelas et al., 2013), $\mathrm{P}$ limitation could become more critical for global SOC sequestration than $\mathrm{N}$ limitation. Both scientific knowledge and traditional farmer's knowledge will be needed to create sustainable agricultural and forestry systems sequestering $C$ in soils without large requirements for additional fertilizers.

\subsection{Synergies with the united nations conventions and resolutions}

The importance of soils has been raised e.g. by the International Year of Soils (2015) and by the first report of the ITPS (FAO and ITPS, 2015). Soils can contribute to the achievement of a number of UN sustainable development goals (SDGs) (Keesstra et al., 2016). Soil C sequestration could bring direct benefits to three SDGs: SDG2: End hunger, achieve food security and improved nutrition and promote sustainable agriculture; SDG13: Take urgent action to combat climate change and its impacts; SDG15: Protect, restore and promote sustainable use of terrestrial ecosystems sustainably manage forests, combat desertification, and halt and reverse land degradation and halt biodiversity loss (FAO, 2017). It can also contribute to the achievement of two other SDGs: SDG6: Ensure availability and sustainable management of water and sanitation for all and SDG12: Ensure sustainable consumption and production patterns.

The interconnectedness of international targets for the AFOLU sector and the opportunity for streamlined action to achieve multiple goals is being increasingly recognized as can be seen from the ongoing reports by the Intergovernmental Science-Policy Platform on Biodiversity and Ecosystem Services (IPBES) on land degradation and biodiversity (IPBES, 2017) and by the launch of the IPCC Special Report on land degradation, food security and climate change. The Global Soil 
Partnership (GSP) for food security and climate change adaptation and mitigation has a knowledge pillar and develops a global soil map, including SOC stocks (GSP, 2017). The UNCCD supports countries to set Land Degradation Neutrality (LDN) targets, in agreement with the SDG target 15.3. This target includes an indicator on SOC stocks, which baseline is currently being established through collaboration between UNCCD and GSP and is supported by the above-cited land degradation neutrality fund (UNCCD Global Mechanism, 2017).

Since 2008, the United Nations collaborative initiative on Reducing Emissions from Deforestation and forest Degradation (UN-REDD) supports country-driven REDD + processes that extend to agriculture and include the restoration of degraded tropical forests supported by the above-cited Bonn challenge.

In this context, the 4 per 1000 initiative can bring added value by collaborating with multiple initiatives and by facilitating local decision making at the field, farm, landscape and regional scales. Any practical implementation (i.e. action plan of the 4 per 1000 initiative) will have to take into account local circumstances and a large number of social and economic factors in order to create useful changes for climate and for food security, while supporting the SDGs and taking into account legitimate concerns for land rights and for human rights, including gender equity (Montanarella, 2015).

\section{Conclusions}

The global aspirational goal of the 4 per 1000 Initiative appears as a technically feasible, no regret, and indispensable climate action. In can be regarded as (i) technically feasible, given its alignment with technical potentials estimated by IPCC, (ii) no-regret for its climate change adaptation and food security benefits, adding to overall climate resilience, and (iii) indispensable for its negative emissions.

Turning the aspirational goal of the ' 4 per 1000 ' soil C initiative into social and economic realities is a challenge that will require the involvement of science to inform policy. A collaborative research program is planned on: i) improved knowledge of the potential and implications (e.g. for yields, non- $\mathrm{CO}_{2}$ GHG emissions, water cycle, etc.) of SOC sequestration; ii) co-design and assessment of agricultural and forestry strategies and practices; iii) defining and strengthening the enabling environment including cost-benefit and value chain analyses, economic and social dimensions, and policy options; iv) metrics and methods for low-cost monitoring, reporting and verifying of soil $\mathrm{C}$ sequestration; v) training and capacity building (4 per 1000 research program, 2017). This research program is needed to support action plans leading to its adoption by multiple stakeholders and by governments worldwide, and to fully understand its multiple implications for sustainable development in contrasted land use and land management systems.

\section{Acknowledgements}

S.L. and F.E. acknowledge the financial support of the French Ministry for Research and Higher Education (4 per 1000 international research program2016-2017 grant).

\section{Appendix A. Supplementary data}

Supplementary data associated with this article can be found, in the online version, at https://doi.org/10.1016/j.still.2017.12.002.

\section{References}

4 per 1000 research program, 2017, (Accessed May 20, 2017) http://www6.inra.fr/ 4p1000science/The-Research-Program.

4 per 1000, 2017. The 4 Per 1000 Initiative. Soils for Food Security and Climate. (Accessed April 26, 2017). http://4p1000. org/.

Assad, E.D., Pinto, H.S., Martins, S.C., Groppo, J.D., Salgado, P.R., Evangelista, B., Vasconcellos, E., Sano, E.E., Pavão, E., Luna, R., Camargo, P.B., Martinelli, L.A.,
2013. Changes in soil carbon stocks in Brazil due to land use: paired site comparisons and a regional pasture soil survey. Biogeosciences 10, 6141-6160. http://dx.doi.org/ 10.5194/bg-10-6141-2013.

Balesdent, J., Arrouays, D., 1999. Usage des terres et stockage de carbone dans les sols du territoire français. Une estimation des flux nets annuels pour la période 1900-1999. C. R. Acad. Agric. Fr. 85, 6.

Barioni, L.G., de Oliveira Silva, R., Moran, D., 2017. Reducing beef consumption might not reduce emissions: response to Phalan et al. (2016). Global Change Biol. 23, e1-e2. http://dx.doi.org/10.1111/gcb.13458.

Batjes, N. h., 1996. Total carbon and nitrogen in the soils of the world. Eur. J. Soil Sci. 47, 151-163. http://dx.doi.org/10.1111/j. 1365-2389.1996. tb01386. x.

Bolin, B., Döös, B.R., Jäger, H.-J., Warwick, R.A., 1986. Scope 29 - The Greenhouse Effect, Climatic Change, and Ecosystems. John Wiley \& Sons, New York, NY, USA.

Branca, G., Lipper, L., McCarthy, N., Jolejole, M.C., 2013. Food security, climate change: and sustainable land management. A review. Agron. Sustainable Dev. 33, 635-650.

Braz, S.P., Urquiaga, S., Alves, B.J.R., Claudia, P., Guimarães, A.P., Santos, D.A.C., Santos, C.D.S., Pinheiro É, É.F.M., Boddey, R.M., 2013. Soil carbon stocks under productive and degraded pastures in the Brazilian Cerrado. Soil Sci. Soc. Am. J. 77, 914-928. http://dx.doi.org/10.2136/sssaj2012.0269.

Campioli, M., Vicca, S., Luyssaert, S., Bilcke, J., Ceschia, E., Chapin Iii, F.S., Ciais, P., Fernández-Martínez, M., Malhi, Y., Obersteiner, M., Olefeldt, D., Papale, D., Piao, S.L., Peñuelas, J., Sullivan, P.F., Wang, X., Zenone, T., Janssens, I.A., 2015. Biomass production efficiency controlled by management in temperate and boreal ecosystems. Nat. Geosci. 8, 843-846. http://dx.doi.org/10.1038/ngeo2553.

Carlson, K.M., Gerber, J.S., Mueller, N.D., Herrero, M., MacDonald, G.K., Brauman, K.A., Havlik, P., O'Connell, C.S., Johnson, J.A., Saatchi, S., West, P.C., 2017. Greenhouse gas emissions intensity of global croplands. Nat. Clim. Change 7, 63-68. http://dx. doi.org/10.1038/nclimate3158.

Chabbi, A., Lehmann, J., Ciais, P., Loescher, H.W., Cotrufo, M.F., Don, A., SanClements, M., Schipper, L., Six, J., Smith, P., Rumpel, C., 2017. Aligning agriculture and climate policy. Nat. Clim. Change 7, 307-309. http://dx.doi.org/10.1038/nclimate3286.

Chappell, A., Baldock, J., Sanderman, J., 2016. The global significance of omitting soil erosion from soil organic carbon cycling schemes. Nat. Clim. Change 6, 187-191. http://dx.doi.org/10.1038/nclimate2829.

Ciais, P., Sabine, C., Bala, G., Bopp, L., Brovkin, V., Canadell, J.G., Chhabra, A., DeFries, R., Galloway, J., Heimann, M., Jones, C., Le Quéré, C., Myneni, R.B., Piao, S., Thornton, P.K., 2013. Carbon and other biogeochemical cycles. Climate Change 2013: The Physical Science Basis. Contribution of Working Group I to the Fifth Assessment Report of the Intergovernmental Panel on Climate Change. Cambridge, United Kingdom and New York, NY, USA.

Conant, R.T., Cerri, C.E.P., Osborne, B.B., Paustian, K., 2017. Grassland management impacts on soil carbon stocks: a new synthesis. Ecol. Appl. 27, 662-668. http://dx. doi.org/10.1002/eap.1473.

Conrad, R., 2009. The global methane cycle: recent advances in understanding the microbial processes involved. Environ. Microbiol. Rep. 1, 285-292. http://dx.doi.org/ 10.1111/j.1758-2229.2009.00038.x.

Corbeels, M., Naudin, K., Guibert, H., Torquebiau, E., Cardinael, R., Is the 4 per Thousand Initiative for soil organic carbon storage achievable in sub-Saharan Africa? Insights from agroforestry and conservation agriculture, (in preparation).

DeLonge, M.S., Ryals, R., Silver, W.L., 2013. A lifecycle model to evaluate carbon sequestration potential and greenhouse gas dynamics of managed grasslands. Ecosystems 16, 962-979. http://dx.doi.org/10.1007/s10021-013-9660-5.

Derpsch, R., Friedrich, T., Kassam, A., Li, H., 2010. Current status of adoption of No-till farming in the world and some of its main benefits. Int. J. Agric. Biol. Eng. 3, 1-25. http://dx.doi.org/10.3965/ijabe.v3i1.223.

Dignac, M.-F., Derrien, D., Barré, P., Barot, S., Cécillon, L., Chenu, C., Chevallier, T., Freschet, G.T., Garnier, P., Guenet, B., Hedde, M., Klumpp, K., Lashermes, G., Maron, P.-A., Nunan, N., Roumet, C., Basile-Doelsch, I., 2017. Increasing soil carbon storage: mechanisms, effects of agricultural practices and proxies. A review. Agron. Sustainable Dev. 37, 14. http://dx.doi.org/10.1007/s13593-017-0421-2.

Dlugokencky, E., Tans, P., 2017. Trends in Atmospheric Carbon Dioxide. NOAAESRL (Accessed April 26, 2017), https://www.esrl.noaa.gov/gmd/ccgg/trends/.

Dumanski, J., Peiretti, R., 2013. Modern concepts of soil conservation. Int. Soil Water Conserv. Res. 1, 19-23. http://dx.doi.org/10.1016/S2095-6339(15)30046-0.

Ellison, D., Morris, C.E., Locatelli, B., Sheil, D., Cohen, J., Murdiyarso, D., Gutierrez, V., Noordwijk van, M., Creed, I.F., Pokorny, J., Gaveau, D., Spracklen, D.V., Tobella, A.B., Ilstedt, U., Teuling, A.J., Gebrehiwot, S.G., Sands, D.C., Muys, B., Verbist, B., Springgay, E., Sugandi, Y., Sullivan, C.A., 2017. Trees, forests and water: cool insights for a hot world. Global Environ. Change 43, 51-61. http://dx.doi.org/10.1016/j. gloenvcha.2017.01.002

FAO and ITPS, 2015. Status of the World's Soil Resources (SWSR) Main Report. Food and Agriculture Organization of the United Nations and Intergovernmental Technical Panel on Soils, Rome, Ita.

FAO, 2017. Voluntary Guidelines for Sustainable Soil Management. Food and Agriculture Organization of the United Nations Rome, Italy.

Fawcett, A.A., Iyer, G.C., Clarke, L.E., Edmonds, J.A., Hultman, N.E., McJeon, H.C., Rogelj, J., Schuler, R., Alsalam, J., Asrar, G.R., Creason, J., Jeong, M., McFarland, J., Mundra, A., Shi, W., 2015. Can Paris pledges avert severe climate change? Science 350, 1168-1169. http://dx.doi.org/10.1126/science.aad5761.

Feng, W., Plante, A.F., Six, J., 2013. Improving estimates of maximal organic carbon stabilization by fine soil particles. Biogeochemistry 112, 81-93. http://dx.doi.org/10. 1007/s10533-011-9679-7.

Fontaine, S., Barot, S., Barré, P., Bdioui, N., Mary, B., Rumpel, C., 2007. Stability of organic carbon in deep soil layers controlled by fresh carbon supply. Nature 450, 277-280. http://dx.doi.org/10.1038/nature06275.

Frank, S., Havlík, P., Soussana, J.-F., Levesque, A., Valin, H., Wollenberg, E., 
Kleinwechter, U., Fricko, O., Gusti, M., Herrero, M., Smith, P., Hasegawa, T., Kraxner, F., Obersteiner, M., 2017. Reducing greenhouse gas emissions in agriculture without compromising food security? Environ. Res. Lett. 12, 105004. http://dx.doi.org/10. 1088/1748-9326/aa8c83.

GFED, 2016. Global Fires Emission Data. (Accessed April 26, 2017). (www. globalfiredata.org/updates.html.

GSP, 2017. The Global Soil Partnership. (Accessed May 20, 2017). http://www.fao.org/ global-soil-partnership/overview/why-the-partnership/en/.

Gerber, P., Steinfeld, H., Henderson, B., Mottet, A., Opio, C., Dijkman, J., Falcucci, A., Tempio, G., 2013. Tackling Climate Change Through Livestock-A Global Assessment of Emissions and Mitigation Opportunities. Food and Agriculture Organization of the United Nations (FAO), Rome, Italy.

Giller, K.E., Witter, E., Corbeels, M., Tittonell, P., 2009. Conservation agriculture and smallholder farming in Africa: the heretics' view. Field Crops Res. 114 (1), 23-34.

Grassi, G., House, J., Dentener, F., Federici, S., den Elzen, M., Penman, J., 2017. The key role of forests in meeting climate targets requires science for credible mitigation. Nat. Clim. Change 7, 220-226. http://dx.doi.org/10.1038/nclimate3227.

Guimarães, D.V., Gonzaga, M.I.S., da Silva, T.O., da Silva, T.L., da Silva Dias, N., Matias, M.I.S., 2013. Soil organic matter pools and carbon fractions in soil under different land uses. Soil Tillage Res. 126, 177-182. http://dx.doi.org/10.1016/j.still.2012.07. 010 .

Haberl, H., Erb, K.-H., Krausmann, F., 2014. Human appropriation of net primary production: patterns trends, and planetary boundaries. Annu. Rev. Environ. Resour. 39, 363-391. http://dx.doi.org/10.1146/annurev-environ-121912-094620.

He, Y., Trumbore, S.E., Torn, M.S., Harden, J.W., Vaughn, L.J.S., Allison, S.D., Randerson, J.T., 2016. Radiocarbon constraints imply reduced carbon uptake by soils during the 21 st century. Science 353, 1419-1424. http://dx.doi.org/10.1126/science.aad4273.

Herrero, M., Henderson, B., Havlík, P., Thornton, P.K., Conant, R.T., Smith, P., ... Butterbach-Bahl, K., 2016. Greenhouse gas mitigation potentials in the livestock sector. Nat. Clim. Change 6, 452-461. http://dx.doi.org/10.1038/nclimate2925.

Herrick, J.E., Sala, O.E., Karl, J.W., 2013. Land degradation and climate change: a sin of omission? Front. Ecol. Environ. 11, 283-383. http://dx.doi.org/10.1890/1540-929511.6.283.

Hiederer, R., Köchy, M., 2011. Global Soil Organic Carbon Estimates and the Harmonized World Soil Database, jrc68528 ed. Publications Office of the European Union, Luxembourg.

Hijbeek, R., Ittersum, M.K., ten Berge, H.F.M., Gort, G., Spiegel, H., Whitmore, A.P., 2017. Do organic inputs matter -a meta-analysis of additional yield effects for arable crops in Europe. Plant Soil 411, 293-303. http://dx.doi.org/10.1007/s11104-016-3031-x.

Houghton, R.A., Byers, B., Nassikas, A.A., 2015. A role for tropical forests in stabilizing atmospheric CO2. Nat. Clim. Change 5, 1022-1023. http://dx.doi.org/10.1038/ nclimate2869.

Houlton, B.Z., Wang, Y.-P., Vitousek, P.M., Field, C.B., 2008. A unifying framework for dinitrogen fixation in the terrestrial biosphere. Nature 454, 327-330. http://dx.doi org/10.1038/nature07028.

IPBES, 2017. Report on Biodiversity, Land Degradation and Restoration. (Accessed May 20, 2017). http://www.ipbes.net/work-programme/land-degradation-andrestoration.

IPCC, 2000. In: Watson, R.T., Noble, I.R., Bolin, B., Ravindranath, N.H., Verardo, D.J., Dokken, D.J. (Eds.), Summary for policymakers: land use, land-use change, and forestry: A special report of the Intergovernmental Panel on Climate Change. Cambridge University Press, UK.

IPCC, 2013. Climate Change 2013: The Physical Science Basis, 2013. In: Stocker, T.F., Qin, D., Plattner, M., Tignor, S.K., Allen, J., Boschung, A., Nauels, Y., Bex, V., Midgley, P.M. (Eds.), Contribution of Working Group I to the Fifth Assessment Report of the Intergovernmental Panel on Climate Change. Cambridge University Press Cambridge, United Kingdom and New York, NY, USA, pp. 2013.

IPCC, 2014. Climate Change 2014: Mitigation of Climate Change, 2014. In: Edenhofer, O., Pichs-Madruga, R., Sokona, Y., Farahani, E., Kadner, S., Seyboth, K., Adler, A., Baum, I., Brunner, S., Eickemeier, P., Kriemann, B., Savolainen, J., Schlömer, S., von Stechow, C., Zwickel, T., Minx, J.C. (Eds.), Contribution of Working Group III to the Fifth Assessment Report of the Intergovernmental Panel on Climate Change. Cambridge University Press Cambridge, United Kingdom and New York, NY, USA.

Jansson, C., Wullschleger, S.D., Kalluri, U.C., Tuskan, G.A., 2010. Phytosequestration: carbon biosequestration by plants and the prospects of genetic engineering. Bioscience 60, 685-696. http://dx.doi.org/10.1525/bio.2010.60.9.6.

Jobbágy, E.G., Jackson, R.B., 2000. The vertical distribution of soil organic carbon and its relation to climate and vegetation. Ecol. Appl. 10, 423-436. http://dx.doi.org/10. 1890/1051-0761(2000)010[0423:TVDOSO]2.0.CO;2.

Keesstra, S.D., Bouma, J., Wallinga, J., Tittonell, P., Smith, P., Cerdà, A., Montanarella, L., Quinton, J.N., Pachepsky, Y., van der Putten, W.H., Bardgett, R.D., Moolenaar, S., Mol, G., Jansen, B., Fresco, L.O., 2016. The significance of soils and soil science towards realization of the United Nations Sustainable Development Goals. Soil 2, 111-128. http://dx.doi.org/10.5194/soil-2-111-2016.

Kirkby, C.A., Kirkegaard, J.A., Richardson, A.E., Wade, L.J., Blanchard, C., Batten, G., 2011. Stable soil organic matter: a comparison of C:N:P:S ratios in Australian and other world soils. Geoderma 163, 197-208. http://dx.doi.org/10.1016/j.geoderma. 2011.04.010.

Kirkby, C.A., Richardson, A.E., Wade, L.J., Passioura, J.B., Batten, G.D., Blanchard, C., Kirkegaard, J.A., 2014. Nutrient availability limits carbon sequestration in arable soils. Soil Biol. Biochem. 68, 402-409.

Lüscher, A., Mueller-Harvey, I., Soussana, J.F., Rees, R.M., Peyraud, J.L., 2014. Potential of legume-based grassland-livestock systems in Europe: a review. Grass Forage Sci. 69, 206-228. http://dx.doi.org/10.1111/gfs.12124.

Lacape, J.-M., Loison, R., Foncéka, D., 2016. Enhanced drought adaptation in african savanna crops. In: Torquebiau, E. (Ed.), Climate Change and Agriculture Worldwide.
Springer, Netherlands, pp. 59-71. http://dx.doi.org/10.1007/978-94-017-7462-8_5.

Lal, R., 2006. Enhancing crop yields in the developing countries through restoration of the soil organic carbon pool in agricultural lands. Land Degrad. Dev. 17, 197-209. http://dx.doi.org/10.1002/ldr.696.

Lal, R., 2010. Managing soils and ecosystems for mitigating anthropogenic carbon emissions and advancing global food security. Bioscience 60, 708-721. http://dx.doi. org/10.1525/bio.2010.60.9.8.

Lal, R., 2016. Global food security and nexus thinking. J. Soil Water Conserv. 71http:// dx.doi.org/10.2489/jswc.71.4.85A. 85A-90A.

Legendre, P., Legendre, L.F.J., 2012. Numerical Ecology. Elsevier.

Le Quéré, C., Moriarty, R., Andrew, R.M., Peters, G.P., Ciais, P., Friedlingstein, P., Jones, S.D., Sitch, S., Tans, P., Arneth, A., Boden, T.A., Bopp, L., Bozec, Y., Canadell, J.G., Chini, L.P., Chevallier, F., Cosca, C.E., Harris, I., Hoppema, M., Houghton, R.A. House, J.I., Jain, A.K., Johannessen, T., Kato, E., Keeling, R.F., Kitidis, V., Klein Goldewijk, K., Koven, C., Landa, C.S., Landschützer, P., Lenton, A., Lima, I.D., Marland, G., Mathis, J.T., Metzl, N., Nojiri, Y., Olsen, A., Ono, T., Peng, S., Peters, W., Pfeil, B., Poulter, B., Raupach, M.R., Regnier, P., Rödenbeck, C., Saito, S., Salisbury, J.E., Schuster, U., Schwinger, J., Séférian, R., Segschneider, J., Steinhoff, T., Stocker, B.D., Sutton, A.J., Takahashi, T., Tilbrook, B., van der Werf, G.R., Viovy, N., Wang, Y.-P., Wanninkhof, R., Wiltshire, A., Zeng, N., 2015. Global carbon budget 2014. Earth Syst. Sci. Data 7, 47-85.

Lipper, L., Thornton, P., Campbell, B.M., Baedeker, T., Braimoh, A., Bwalya, M., Caron, P., Cattaneo, A., Garrity, D., Henry, K., Hottle, R., Jackson, L., Jarvis, A., Kossam, F., Mann, W., McCarthy, N., Meybeck, A., Neufeldt, H., Remington, T., Sen, P.T., Sessa, R., Shula, R., Tibu, A., Torquebiau, E.F., 2014. Climate-smart agriculture for food security. Nat. Clim. Change 4, 1068-1072. http://dx.doi.org/10.1038/nclimate2437.

Lorenz, K., Lal, R., 2014. Soil organic carbon sequestration in agroforestry systems. A review. Agron. Sust. Dev. 34 (2), 443-454.

Lowder, S.K., Skoet, J., Singh, S., 2014. What Do We Really Know About the Number and Distribution of Farms and Family Farms Worldwide? Background Paper for The State of Food and Agriculture 2014. ESA Working Paper No. 14-02. Rome, FAO.

Lugato, E., Paustian, K., Panagos, P., Jones, A., Borrelli, P., 2016. Quantifying the erosion effect on current carbon budget of European agricultural soils at high spatial resolution. Global Change Biol. 22 (5), 1976-1984.

Luo, Z., Wang, E., Sun, O.J., 2010. Can no-tillage stimulate carbon sequestration in agricultural soils? A meta-analysis of paired experiments. Agric. Ecosyst. Environ. 139, 224-231. http://dx.doi.org/10.1016/j.agee.2010.08.006.

Lutfalla, S., Abiven, S., Barré, P., Wiedemeier, D.B., Christensen, B.T., Houot, S., Kätterer, T., Macdonald, A.J., van Oort, F., Chenu, C., 2017. Pyrogenic carbon lacks long-Term persistence in temperate arable soils. Front. Earth Sci. 5, 96. http://dx.doi.org/10. 3389/feart.2017.00096.

Minasny, B., Malone, B.P., McBratney, A.B., Angers, D.A., Arrouays, D., Chambers, A., Chaplot, V., Chen, Z.-S., Cheng, K., Das, B.S., Field, D.J., Gimona, A., Hedley, C.B., Hong, S.Y., Mandal, B., Marchant, B.P., Martin, M., McConkey, B.G., Mulder, V.L., O’Rourke, S., Richer-de-Forges, A.C., Odeh, I., Padarian, J., Paustian, K., Pan, G., Poggio, L., Savin, I., Stolbovoy, V., Stockmann, U., Sulaeman, Y., Tsui, C.-C., Vågen, T.-G., van Wesemael, B., Winowiecki, L., 2017. Soil carbon 4 per mille. Geoderma 292, 59-86. http://dx.doi.org/10.1016/j.geoderma.2017.01.002.

Montanarella, L., 2015. Agricultural policy: govern our soils. Nat. News 528, 32. http:// dx.doi.org/10.1038/528032a.

Mukherjee, A., Lal, R., 2014. The biochar dilemma. Soil Res. 52, 217-230. http://dx.doi. org/10.1071/SR13359.

Nabuurs, G.J., Masera, O., Andrasko, K., Benitez-Ponce, P., Boer, R., Dutschke, M., Elsiddig, E., Ford-Robertson, J., Frumhoff, P., Karjalainen, T., Krankina, O., Kurz, W.A., Matsumoto, M., Oyhantcabal, W., Ravindranath, N.H., Sanz Sanchez, M.J., Zhang, X., 2007. Forestry. In Climate Change 2007: Mitigation. Contribution of Working Group III to the Fourth Assessment Report of the Intergovernmental Panel on Climate Change. (Cambridge, United Kingdom and New York, NY, USA).

Nair, P.K.R., Mohan Kumar, B., Nair, V.D., 2009. Agroforestry as a strategy for carbon sequestration. J. Plant Nutr. Soil Sci. 172, 10-23. http://dx.doi.org/10.1002/jpln. 200800030.

Ogle, S.M., Breidt, F.J., Paustian, K., 2005. Agricultural management impacts on soil organic carbon storage under moist and dry climatic conditions of temperate and tropical regions. Biogeochem 72, 87-121.

Orr, B.J., Cowie, A., Castillon Sanchez, V.M., Chasek, P., Crossman, N.D., Erlewein, A., Louwagie, G., Maron, M., Metternicht, G.I., Minelli, S., Tengberg, A.E., Walter, S., Welton, S., 2017. Scientific Conceptual Framework for Land Degradation Neutrality. A Report of the Science-Policy Interface. United Nations Convention to Combat Desertification (UNCCD), Bonn, Germany No. ISBN 978-92-95110-42-7.

Page, S.E., Siegert, F., Rieley, J.O., Boehm, H.-D.V., Jaya, A., Limin, S., 2002. The amount of carbon released from peat and forest fires in Indonesia during 1997. Nature 420, 61-65. http://dx.doi.org/10.1038/nature01131.

Pan, G., Smith, P., Pan, W., 2009. The role of soil organic matter in maintaining the productivity and yield stability of cereals in China. Agric. Ecosyst. Environ. 129, 344-348. http://dx.doi.org/10.1016/j.agee.2008.10.008.

Pan, Y., Birdsey, R.A., Fang, J., Houghton, R., Kauppi, P.E., Kurz, W.A., Phillips, O.L. Shvidenko, A., Lewis, S.L., Canadell, J.G., Ciais, P., Jackson, R.B., Pacala, S.W., McGuire, A.D., Piao, S., Rautiainen, A., Sitch, S., Hayes, D., 2011. A large and persistent carbon sink in the world's forests. Science 333, 988-993.

Paustian, K., Lehmann, J., Ogle, S., Reay, D., Robertson, G.P., Smith, P., 2016. Climatesmart soils. Nature 532, 49-57. http://dx.doi.org/10.1038/nature17174.

Peñuelas, J., Poulter, B., Sardans, J., Ciais, P., Velde van der, M., Bopp, L., Boucher, O., Godderis, Y., Hinsinger, P., Llusia, J., Nardin, E., Vicca, S., Obersteiner, M., Janssens, I.A., 2013. Human-induced nitrogen-phosphorus imbalances alter natural and managed ecosystems across the globe. Nat. Commun. 4, 2934. http://dx.doi.org/10. 1038/ncomms3934. 
Phalan, B., Ripple, W.J., Smith, P., 2016. Increasing beef production won't reduce emissions. Global Change Biol. 22, 3255-3256. http://dx.doi.org/10.1111/gcb. 13436.

Pittelkow, C.M., Liang, X., Linquist, B.A., van Groenigen, K.J., Lee, J., Lundy, M.E., van Gestel, N., Six, J., Venterea, R.T., van Kessel, C., 2015. Productivity limits and potentials of the principles of conservation agriculture. Nature 517, 365-368. http://dx. doi.org/10.1038/nature13809.

Poeplau, C., Don, A., 2015. Carbon sequestration in agricultural soils via cultivation of cover crops-A meta-analysis. Agric. Ecosyst. Environ. 200, 33-41. http://dx.doi.org/ 10.1016/j.agee.2014.10.024

Popp, A., Calvin, K., Fujimori, S., Havlik, P., Humpenöder, F., Stehfest, E., Bodirsky, B.L., Dietrich, J.P., Doelmann, J.C., Gusti, M., Hasegawa, T., Kyle, P., Obersteiner, M., Tabeau, A., Takahashi, K., Valin, H., Waldhoff, S., Weindl, I., Wise, M., Kriegler, E., Lotze-Campen, H., Fricko, O., Riahi, K., Vuuren, D.P.v., 2017. Land-use futures in the shared socio-economic pathways. Global Environ. Change 42, 331-345.

Powlson, D.S., Stirling, C.M., Jat, M.L., Gerard, B.G., Palm, C.A., Sanchez, P.A., Cassman, K.G., 2014. Limited potential of no-till agriculture for climate change mitigation. Nat. Clim. Change 4, 678-683. http://dx.doi.org/10.1038/nclimate2292.

Richards, M., Bruun, T.B., Campbell, B.M., Le, G., Huyer, S., Kuntze, V., Stn, M., Oldvig, Mb., Vasileiou, I., 2016. How Countries Plan to Address Agricultural Adaptation and Mitigation: An Analysis of Intended Nationally Determined Contributions. (CCAFS dataset).

Rosenstock, T.S., Lamanna, C., Chesterman, S., Bell, P., Arslan, A., Richards, M., Rioux, J., Akinleye, A., Champalle, C., Cheng, Z., Corner-Dolloff, C., Dohn, J., English, W., Eyrich, A., Girvetz, E.H., Kerr, A., Lizarazo, M., Madalinska, A., McFatridge, S., Morris, K., Namoi, N., Poultouchidou, N., Ravina da Silva, M., Rayess, S., Ström, H., Tully, K., Zhou, W., 2016. The Scientific Basis of Climate-smart Agriculture: A Systematic Review Protocol (CCAFS Working Paper No. 138). CGIAR Research Program on Climate Change. Agriculture and Food Security (CCAFS), Copenhagen, Denmark

Scharlemann, J.P., Tanner, E.V., Hiederer, R., Kapos, V., 2014. Global soil carbon: understanding and managing the largest terrestrial carbon pool. Carbon Manage. 5, 81-91. http://dx.doi.org/10.4155/cmt.13.77.

Schmidt, M.W.I., Torn, M.S., Abiven, S., Dittmar, T., Guggenberger, G., Janssens, I.A. Kleber, M., Kögel-Knabner, I., Lehmann, J., Manning, D.A.C., Nannipieri, P., Rasse, D.P., Weiner, S., Trumbore, S.E., 2011. Persistence of soil organic matter as an ecosystem property. Nature 478, 49-56. http://dx.doi.org/10.1038/nature10386.

Sinclair, T.R., 1998. Historical changes in harvest index and crop nitrogen accumulation. Crop Sci. 38, 638-643. http://dx.doi.org/10.2135/cropsci1998. 0011183x003800030002x.

Six, J., Conant, R.T., Paul, E.A., Paustian, K., 2002. Stabilization mechanisms of soil organic matter: implications for C-saturation of soils. Plant Soil 241, 155-176. http:// dx.doi.org/10.1023/A:1016125726789.

Smith, P., Martino, D., Cai, Z, Gwary, D, Janzen, H., Kumar, P., McCarl, B., Ogle, S., O'Mara, F., Rice, C., Scholes, B., Sirotenko, O., Howden, M., McAllister, T., Pan, G., Romanenkov, V., Schneider, U., Towprayoon, S., Wattenbach, M., Smith, J., 2008. Greenhouse gas mitigation in agriculture. Philos. Trans. R. Soc. Lond. B Biol. Sci. 363, 789-813. http://dx.doi.org/10.1098/rstb.2007.2184.

Smith, P., Haberl, H., Popp, A., Erb, K., Lauk, C., Harper, R., Tubiello, F.N., de Siqueira Pinto, A., Jafari, M., Sohi, S., Masera, O., Böttcher, H., Berndes, G., Bustamante, M., Ahammad, H., Clark, H., Dong, H., Elsiddig, E.A., Mbow, C., Ravindranath, N.H., Rice, C.W., Robledo Abad, C., Romanovskaya, A., Sperling, F., Herrero, M., House, J.I., Rose, S., 2013. How much land-based greenhouse gas mitigation can be achieved without compromising food security and environmental goals? Global Change Biol 19, 2285-2302. http://dx.doi.org/10.1111/gcb.12160.

Smith, P., Bustamante, M., Ahammad, H., Clark, H., Dong, H., Elsiddig, E.A., Haberl, H., Harper, R., House, J.I., Jafari, M., Masera, O., Mbow, C., Ravindranath, N.H., Rice, C.W., Robledo Abad, C., Romanovskaya, A., Sperling, F., Tubiello, F.N., 2014. Agriculture, forestry and other land use (AFOLU). Climate Change 2014: Mitigation of Climate Change. Contribution of Working Group III to the Fifth Assessment Report of the Intergovernmental Panel on Climate Change. (Cambridge, United Kingdom and New York, NY, USA).

Smith, P., Davis, S.J., Creutzig, F., Fuss, S., Minx, J., Gabrielle, B., Kato, E., Jackson, R.B., Cowie, A., Kriegler, E., van Vuuren, D.P., Rogelj, J., Ciais, P., Milne, J., Canadell, J.G., McCollum, D., Peters, G., Andrew, R., Krey, V., Shrestha, G., Friedlingstein, P., Gasser, T., Grübler, A., Heidug, W.K., Jonas, M., Jones, C.D., Kraxner, F., Littleton, E., Lowe, J., Moreira, J.R., Nakicenovic, N., Obersteiner, M., Patwardhan, A., Rogner, M., Rubin, E., Sharifi, A., Torvanger, A., Yamagata, Y., Edmonds, J., Yongsung, C., 2016. Biophysical and economic limits to negative CO2 emissions. Nat. Clim. Change 6, 42-50. http://dx.doi.org/10.1038/nclimate2870.

Sommer, R., Bossio, D., 2014. Dynamics and climate change mitigation potential of soil organic carbon sequestration. J. Environ. Manage. 144, 83-87. http://dx.doi.org/10. 1016/j.jenvman.2014.05.017.

Soussana, J.-F., Lemaire, G., 2014. Coupling carbon and nitrogen cycles for environmentally sustainable intensification of grasslands and crop-livestock systems. Agric. Ecosyst. Environ. 190, 9-17. http://dx.doi.org/10.1016/j.agee.2013.10.012. Integrated Crop-Livestock System Impacts on Environmental Processes.

Soussana, J.F., Tallec, T., Blanfort, V., 2010. Mitigating the greenhouse gas balance of ruminant production systems through carbon sequestration in grasslands. Animal 4 334-350. http://dx.doi.org/10.1017/S1751731109990784.

Stockmann, U., Adams, M.A., Crawford, J.W., Field, D.J., Henakaarchchi, N., Jenkins, M., Minasny, B., McBratney, A.B., Courcelles de de, V.R., Singh, K., Wheeler, I., Abbott, L., Angers, D.A., Baldock, J., Bird, M., Brookes, P.C., Chenu, C., Jastrow, J.D., Lal, R. Lehmann, J., O’Donnell, A.G., Parton, W.J., Whitehead, D., Zimmermann, M., 2013. The knowns, known unknowns and unknowns of sequestration of soil organic carbon. Agric. Ecosyst. Environ. 164, 80-99. http://dx.doi.org/10.1016/j.agee.2012.10.001.

The Bonn Challenge, 2017, (Accessed April 26, 2017) http://www.bonnchallenge.org/ content/challenge.

Tian, H., Lu, C., Ciais, P., Michalak, A.M., Canadell, J.G., Saikawa, E., Huntzinger, D.N., Gurney, K.R., Sitch, S., Zhang, B., Yang, J., Bousquet, P., Bruhwiler, L., Chen, G., Dlugokencky, E., Friedlingstein, P., Melillo, J., Pan, S., Poulter, B., Prinn, R., Saunois, M., Schwalm, C.R., Wofsy, S.C., 2016. The terrestrial biosphere as a net source of greenhouse gases to the atmosphere. Nature 531, 225-228. http://dx.doi.org/10. 1038/nature16946.

Torquebiau, E.F., Kwesiga, F., 1996. Root development in a Sesbania sesban fallow-maize system in Eastern Zambia. Agrofor. Syst. 34, 193-211. http://dx.doi.org/10.1007/ BF00148162.

UNCCD Global Mechanism, 2017, (Accessed on May 20, 2017) http://www2.unccd.int/ about-us/global-mechanism.

UNEP, 2015. The Emissions Gap Report United Nations Environment Programme (UNEP). (Nairobi. ed).

Virto, I., Barré, P., Burlot, A., Chenu, C., 2012. Carbon input differences as the main factor explaining the variability in soil organic $\mathrm{C}$ storage in no-tilled compared to inversion tilled agrosystems. Biogeochemistry 108, 17-26. http://dx.doi.org/10.1007/s10533011-9600-4.

WOCAT, 2017. The World Overview of Conservation Approaches and Technologies. (Accessed April 26, 2017). https://www.wocat.net/en/about-wocat.html.

Walsh, B., Ciais, P., Janssens, I.A., Peñuelas, J., Riahi, K., Rydzak, F., Vuuren van, D.P., Obersteiner, M., 2017. Pathways for balancing CO2 emissions and sinks. Nat. Commun. 8, 14856. http://dx.doi.org/10.1038/ncomms14856.

Wang, Z., Hoffmann, T., Six, J., Kaplan, J.O., Govers, G., Doetterl, S., Van Oost, K., 2017. Human-induced erosion has offset one-third of carbon emissions from land cover change. Nat. Clim. Change 7, 345-349. http://dx.doi.org/10.1038/nclimate3263.

Ward, S.E., Smart, S.M., Quirk, H., Tallowin, J.R.B., Mortimer, S.R., Shiel, R.S., Wilby, A., Bardgett, R.D., 2016. Legacy effects of grassland management on soil carbon to depth. Global Change Biol. 22, 2929-2938. http://dx.doi.org/10.1111/gcb.13246.

Wollenberg, E., Richards, M., Smith, P., Havlík, P., Obersteiner, M., Tubiello, F.N., Herold, M., Gerber, P., Carter, S., Reisinger, A., van Vuuren, D.P., Dickie, A., Neufeldt, H., Sander, B.O., Wassmann, R., Sommer, R., Amonette, J.E., Falcucci, A., Herrero, M., Opio, C., Roman-Cuesta, R.M., Stehfest, E., Westhoek, H., OrtizMonasterio, I., Sapkota, T., Rufino, M.C., Thornton, P.K., Verchot, L., West, P.C., Soussana, J.-F., Baedeker, T., Sadler, M., Vermeulen, S., Campbell, B.M., 2016. Reducing emissions from agriculture to meet the $2^{\circ} \mathrm{C}$ target. Global Change Biol. 22, 3859-3864. http://dx.doi.org/10.1111/gcb.13340.

WorldBank, 2017. Global Economic Monitor (GEM) Commodities. (Accessed June 2, 2017). http://databank.worldbank.org/data/databases/commodity-price-data.

Worldwatch Institute, 2017. Agricultural Subsidies Remain a Staple in the Industrial World. (Accessed April 26, 2017). http://www.worldwatch.org/agriculturalsubsidies-remain-staple-industrial-world-0.

Yin, Y., Ciais, P., Chevallier, F., van der Werf, G.R., Fanin, T., Broquet, G., Boesch, H., Cozic, A., Hauglustaine, D., Szopa, S., Wang, Y., 2016. Variability of fire carbon emissions in equatorial Asia and its nonlinear sensitivity to El Niño. Geophys. Res. Lett. 43http://dx.doi.org/10.1002/2016GL070971. (2016GL070971).

Zomer, R.J., Neufeldt, H., Xu, J., Ahrends, A., Bossio, D., Trabucco, A., van Noordwijk, M., Wang, M., 2016. Global Tree Cover and Biomass Carbon on Agricultural Land: the contribution of agroforestry to global and national carbon budgets. Sci. Rep. 6 . http://dx.doi.org/10.1038/srep29987.

de Oliveira Silva, R., Barioni, L.G., Hall, J.A.J., Folegatti Matsuura, M., Zanett Albertini, T., Fernandes, F.A., Moran, D., 2016. Increasing beef production could lower greenhouse gas emissions in Brazil if decoupled from deforestation. Nat. Clim. Change 6, 493-497. http://dx.doi.org/10.1038/nclimate2916.

van Groenigen, J.W., van Kessel, C., Hungate, B.A., Oenema, O., Powlson, D.S., van Groenigen, K.J., 2017. Sequestering soil organic carbon: a nitrogen dilemma. Environ. Sci. Technol. 51, 4738-4739. http://dx.doi.org/10.1021/acs.est.7b01427.

van Kessel, C., Venterea, R., Six, J., Adviento-Borbe, M.A., Linquist, B., van Groenigen, K.J., 2013. Climate, duration, and $\mathrm{N}$ placement determine $\mathrm{N} 2 \mathrm{O}$ emissions in reduced tillage systems: a meta-analysis. Global Change Biol. 19, 33-44. http://dx.doi.org/10 1111/j.1365-2486.2012.02779.x. 